NBER WORKING PAPER SERIES

\title{
OVERCONFIDENCE AND EARLY-LIFE EXPERIENCES: \\ THE IMPACT OF MANAGERIAL TRAITS ON CORPORATE FINANCIAL POLICIES
}

\author{
Ulrike Malmendier \\ Geoffrey Tate \\ Jonathan Yan \\ Working Paper 15659 \\ http://www.nber.org/papers/w15659
}

\author{
NATIONAL BUREAU OF ECONOMIC RESEARCH \\ 1050 Massachusetts Avenue \\ Cambridge, MA 02138 \\ January 2010
}

\begin{abstract}
We are indebted to Brian Hall, David Yermack and John Graham for providing us with the data. We thank Malcolm Baker, Rudi Fahlenbrach, Michael Faulkender, Murray Frank, Dirk Hackbarth, Dirk Jenter, Jeremy Stein, Ilya Strebulaev, Avanidhar Subrahmanyam, Jeffrey Wurgler and seminar participants at the Berkeley, Calgary, Columbia, Helsinki School of Economics, Insead, MIT, Rotterdam, Stanford, UCLA, USC, Wharton (Applied Economics), Zurich and at the AEA, AFA, FEA, Frontiers in Finance (Banff), IZA Behavioral Economics of Organizations, and Olin Corporate Governance conferences for helpful comments. Nishanth Rajan provided excellent research assistance. Ulrike Malmendier would like to thank the Coleman Fung Risk Management Research Center for financial support. An earlier version of this paper was titled "Corporate Financial Policies With Overconfident Managers." The views expressed herein are those of the authors and do not necessarily reflect the views of the National Bureau of Economic Research.
\end{abstract}

NBER working papers are circulated for discussion and comment purposes. They have not been peerreviewed or been subject to the review by the NBER Board of Directors that accompanies official NBER publications.

(C) 2010 by Ulrike Malmendier, Geoffrey Tate, and Jonathan Yan. All rights reserved. Short sections of text, not to exceed two paragraphs, may be quoted without explicit permission provided that full credit, including $\odot$ notice, is given to the source. 
Overconfidence and Early-life Experiences: The Impact of Managerial Traits on Corporate

Financial Policies

Ulrike Malmendier, Geoffrey Tate, and Jonathan Yan

NBER Working Paper No. 15659

January 2010, Revised December 2010

JEL No. D03,D21,D23,D53,D82,G14,G3,G31,G32,H2,H32

\begin{abstract}
We show that measurable managerial characteristics have significant explanatory power for corporate financing decisions beyond traditional capital-structure determinants. First, managers who believe that their firm is undervalued view external financing as overpriced, especially equity. Such overconfident managers use less external finance and, conditional on accessing risky capital, issue less equity than their peers. Second, CEOs with Depression experience are averse to debt and lean excessively on internal finance. Third, CEOs with military experience pursue more aggressive policies, including heightened leverage. Complementary measures of CEO traits based on press portrayals confirm the results.
\end{abstract}

Ulrike Malmendier

Department of Economics

549 Evans Hall \# 3880

University of California, Berkeley

Berkeley, CA 94720-3880

and NBER

ulrike@econ.berkeley.edu

Geoffrey Tate

Finance Department - Rm C420

UCLA Anderson School of Management

110 Westwood Plaza

Los Angeles, CA 90095

geoff.tate@anderson.ucla.edu
Jonathan Yan

Graduate School of Business

518 Memorial Way

Stanford University

Stanford, CA 94305

jonathan.yan@stanford.edu

An online appendix is available at:

http://www.nber.org/data-appendix/w15659 
What are the primary determinants of firms' financing decisions? Traditional theories emphasize firm-, industry-, and market-level explanations, such as the trade-off between tax deductibility of interest payments and bankruptcy costs, or asymmetric information between firms and the capital market (Miller (1977); Myers (1984); Myers and Majluf (1984)). These theories explain a significant portion of the observed variation in capital structure. Yet, recent research identifies firm-specific stickiness in capital structure that is not a clear prediction of the traditional theories (Lemmon et al. (2008)). Moreover, modern dynamic theories of optimal capital structure allow room for firms with similar fundamentals to operate away from a common target capital structure, but the factors which predict these differences are less clear.

In this paper, we study the role of managerial traits in explaining the remaining variation. We measure capital-structure relevant beliefs revealed by CEOs' personal portfolio choices (overconfidence) and identify formative personal experiences early in life (Great Depression, military). Our approach builds on a growing literature showing that individual top-level managers significantly affect corporate decisions and performance, above and beyond firm-, industry-, and market-specific determinants (Weisbach (1995); Chevalier and Ellison (1999); Bertrand and Schoar (2003)). However, this literature says little about the specific managerial characteristics that matter and why. The lack of specific predictions, in turn, makes it hard to establish a causal impact on corporate decisions. In this paper, we derive specific implications for financial decision-making and confirm the importance of managerial traits in explaining observed variation in corporate capital structure.

First, we consider managers who overestimate their firms' future cash flows and, hence, believe that their firms are undervalued by the market. We show that overconfident managers view external financing to be unduly costly and prefer to use cash or riskless debt. Conditional on having to raise risky capital, they prefer debt to equity, since equity prices are more sensitive to differences of opinions about future cash flows. Unconditionally, they may choose low levels of risky debt relative to available interest tax deductions (and even lower levels of equity).

Second, we consider variation in managers' personal histories that is likely to generate differences in their financial decision-making. Existing evidence suggests that individuals are most affected by seismic events early in life (see, e.g., Elder (1998)). We identify the two biggest shocks that are likely to be formative experiences and that affect a significant portion of our sample CEOs early in life: growing up during the Great Depression and serving in the military. Depression CEOs have less faith in external capital markets (Graham and Narasimhan (2004); Schoar (2007); Malmendier and Nagel (2009)). They therefore lean excessively on internal financing. Military service during early adulthood and, particularly, combat exposure have a lasting impact on veterans' life-choices and decision making (Elder (1986); Elder and Clipp (1989); Elder, Gimbel, and Ivie (1991)) and induce agressiveness or risk-taking. These traits may later manifest themselves in more aggressive capital structure choices.

We measure overconfidence using data on CEO option-holdings. First, we use detailed 
data from large U.S. companies between 1980 and 1994 to identify CEOs who systematically maintain high personal exposure to company-specific risk. The CEOs in our data have a strong incentive to diversify their personal portfolios since they receive substantial equitybased compensation and since the value of their human capital depends on firm performance. Yet, some CEOs hold non-tradeable, in-the-money executive stock options until expiration rather than exercising them after the vesting period. This delay in exercise, captured by the "Longholder" measure from Malmendier and Tate (2008) and (2005), is not explained by insider knowledge, as it does not yield abnormal returns over a simple strategy of exercising and diversifying. A plausible interpretation is that these CEOs overestimate the means of their firms' future cash-flows. ${ }^{1}$ We address several alternative interpretations, including signaling and risk tolerance, and we separate years before and after a CEO first displays Longholder behavior ("Pre-" and "Post-Longholder"). As an alternative measure, we identify CEOs who do not exercise options that are highly in the money (67\%) five years prior to expiration ("Holder 67 "). ${ }^{2}$ As a robustness check, we also construct analogous portfolio measures using CEO compensation and insider trading data from Execucomp and Thomson Financial from 1992 to 2007. Though data limitations preclude us from classifying CEOs with the same precision as in the earlier sample, these measures allow us to conduct "out-of-sample" tests confirming the generalizability of our key results to more recent data. Finally, we consider an alternative to our portfolio-based measures, instead identifying CEOs' beliefs based on their portrayal as "confident" or "optimistic" in the business press.

We measure Depression experience using birth years in the decade leading up to the Great Depression. And we measure military experience based on hand-collected information from Dun and Bradstreet and Who's Who in Finance and Industry. We use information on service years to identify veterans of World War II, the Korean War, and the Vietnam War. As with overconfidence, we use press coverage to sharpen the interpretation of our measures: Press coverage as "cautious," "conservative," or in similar terms is positively correlated with membership in the Depression cohort, but negatively with military experience.

We then relate our measures of overconfidence and formative experiences to corporate financial policies. Using SDC data on security issuance, we find that overconfident CEOs are

\footnotetext{
${ }^{1} \mathrm{~A}$ different behavioral bias sometimes referred to as 'overconfidence' is the underestimation of variance (e.g., in Ben-David, Graham, and Harvey (2007)). This bias does not have a clear implication for the timing of option exercise. It implies an underestimation rather than overestimation of option value, predicting expedited option exercise. But, assuming that CEOs exercise executive options for the purpose of selling the stock (consistent, e.g., with the evidence in Ofek and Yermack (2000)), it also implies lower perceived benefits of diversification and, hence, delayed exercise. Delayed option exercise is unambiguously predicted only by the type of overconfidence analyzed in this paper, i.e., the overestimation of mean future cash flows. Moreover, the capital-structure implications of underestimation of the variance are reverse (Hackbarth, forthcoming), which allows us to empirically distinguish which bias dominates.

${ }^{2}$ The $67 \%$ threshold comes from the rational option exercise model of Hall and Liebman (2002) with constant relative risk aversion of 3 and $67 \%$ of wealth in company stock.
} 
significantly less likely to issue equity conditional on accessing public markets. For example, Longholder CEOs issue equity in only $31 \%$ of years in which they access public markets, compared to $42 \%$ among their peers. We find the same pattern using accounting data from Compustat, which includes private financing, and the methodology of Shyam-Sunder and Myers (1999): Longholder CEOs raise roughly 35 cents more debt than rational predecessors or successors in the same firm to meet an additional dollar of external financing needs. The aversion to equity is strong enough to have a cumulative effect on firm leverage: Firms have significantly higher leverage ratios in years in which they employ overconfident CEOs.

We also test whether overconfident CEOs are generally more reluctant to access external capital markets, preferring instead to rely on internal sources of finance. While not a necessary implication, overconfidence offers a possible explanation for the evidence in prior papers that firms in general do not issue enough debt. Using the 'kink' methodology from Graham (2000), we find that overconfident CEOs are significantly more likely to under-utilize debt relative to available tax benefits. At the same time, they do not abstain from issuing riskless debt, i.e., debt with high S\&P long term credit ratings, for which there is no disagreement about the appropriate interest rate. Moreover, the most debt-conservative overconfident CEOs are also equity-conservative: they are least likely to issue equity.

We find that Depression CEOs are more prone to under-utilize debt relative to its tax benefits than the average CEO. And they do not substitute equity issuance for debt, confirming their aversion to risky capital markets. On the other hand, CEOs with prior military service, particularly those who served in World War II, choose more aggressive capital structures. Under their leadership, market leverage ratios are significantly higher than under their predecessors or successors. The results on Word War II veterans are particularly important since, due to the draft, they alleviate concerns about self-selection into service.

Our findings demonstrate the importance of managerial traits for financing decisions, both within and between firms. The predictive power of CEO traits for financing decisions also implies limitations in the ability of existing compensation contracts and governance mechanisms to perfectly align managerial preferences with those of diversified shareholders.

Our analysis uses identifiable traits of CEOs, but not of CFOs, for whom we do not have data on personal characteristics and portfolio choices. ${ }^{3}$ As a result, our findings allow for two interpretations: (1) CEOs directly determine financing, or (2) CFOs determine financing, but their decisions are positively correlated with CEO traits (assortative matching). For the decisions considered in our analysis, it is likely that CEOs have the ultimate say. While CFOs first design financing decisions, the CEO alone can withdraw (or approve of) a stock offering at the last moment (Hechinger (1998)) or overrule the CFO and treasurer (Whitford (1999)). ${ }^{4}$

\footnotetext{
${ }^{3}$ The ExecuComp data on the top five executives in S\&P 1500 firms is not as detailed, often missing for CFOs, and available for a shorter time frame. It overlaps with our main sample period for only two years.

${ }^{4}$ It is not unusual for CEOs to reject the CFO's financing plan, especially when asset sales are involved
} 
Our findings relate to several strands of literature. Our analysis of overconfidence contributes to the literature linking biased managerial beliefs to corporate decisions, initiated by Roll (1986). In the context of financing, Heaton (2002) models a bias in the perceived probability of high cash flow, which affects both the first and the second moments of the perceived cash flow distribution. Similarly, Hackbarth (forthcoming) models distortions to both the mean and the variance. Our approach differs by focusing on the overestimation of mean future cash flows. Malmendier and Tate (2005) consider a similar model and show that investment by overconfident CEOs is more sensitive to cash flow, particularly in firms with low debt capacity.

Empirically, Graham and Harvey's (2001) CFO Outlook Survey suggests a direct role for biased managerial beliefs in financing choices. For example, in the second quarter of 1999, prior to the end of the technology bubble, roughly $70 \%$ of respondents state that their company stock is undervalued, and $67 \%$ say that misvaluation is an important factor in the decision to issue stock. Ben-David, Graham, and Harvey (2007) relate the mis-calibration bias of CFOs revealed in such surveys to a wide range of corporate decisions, including corporate financing.

The psychology literature suggests that executives are particularly prone to exhibit overconfidence. ${ }^{5}$ Possible reasons include sorting of high-confidence individuals into top positions (Goel and Thakor (forthcoming)); self-attribution bias induced by past successes, such as those necessary to become CEO, (Miller and Ross (1975), Billett and Qian(2007)); and illusion of control. ${ }^{6}$

Our results fill a critical gap in the literature by directly linking CEO overconfidence to financing choices in large U.S. firms. Though preferences among different financing instruments are an implicit prediction in much of the literature, ${ }^{7}$ to our knowledge, this prediction remains untested using field data from corporations.

Our results on past experiences of CEOs (Great Depression, military service) build on research exploring the effects of prior life experiences on economic decision-making. Donaldson (1990) argues that corporate leaders who were young adults in the 1930s were "profoundly affected by the collapse of the capital markets during the Great Depression," leading them to be "deeply skeptical of the public capital markets as a reliable source of personal or corporate funding," and "to have an instinctive affinity for a strategy of self-sufficiency" (p. 125). Consistent with this view, Graham and Narasimhan (2004) find that Depression-era CEOs chose lower leverage in the 1940s than other CEOs. More broadly, Schoar (2007) shows that CEOs who start their career in a recession make more conservative capital-structure choices, e.g., choose lower leverage and internal over external growth. Malmendier and Nagel (2008)

(Millman (2001)). Recent jury verdicts against CEOs of firms with financial scandals imply the same view.

${ }^{5}$ Larwood and Whittaker (1977); Kidd (1970); Moore (1977).

${ }^{6}$ Langer (1975), Weinstein (1980), Alicke et al. (1995), and March and Shapira (1987) argue, more generally, that individuals overestimate their ability to control outcomes and underestimate the likelihood of failure.

${ }^{7}$ See the survey by Baker, Ruback, and Wurgler (2006). Recent work also includes Hietala, Kaplan, and Robinson (2003); Landier and Thesmar (forthcoming); and Lowe and Ziedonis (2006). 
find related evidence that past economic shocks have a long-lasting effect on individual risk aversion and deter risky financial investment decisions such as stock-market participation. Similarly, Oyer (2008) finds that stock market shocks while MBA students are in school have long-lasting career impacts. A large medical and psychology literature examines the impact of military exposure on post-war behavior. Berkowitz and Lepage (1967) find that weapons are "aggression-eliciting stimuli," and Killgore et al. (2008) show that combat exposure increases risky behavior upon returning from deployment. Wansink et al. (2008) provide evidence of higher risk-taking propensity among World War II veterans. Elder (1986); Elder and Clipp (1989); and Elder, Gimbel, and Ivie (1991) argue that the skills learned from combat make individuals more convinced that they can handle stressful and risky situations, resulting in less risk aversion and higher assertiveness.

Our findings also contribute to the broader empirical literature identifying fixed managerial effects on corporate policies (Bertrand and Schoar (2003), Frank and Goyal (2007b)). We go beyond prior studies by identifying specific managerial beliefs (overconfidence) and experiences early in life (Depression, military) that affect financing choices and that can be formalized in a predictive economic model. To the extent that managerial beliefs and the impact of past experiences are sticky they can also help to explain the strong firm fixed-effects identified in the recent capital-structure literature (Lemmon et al. (2008)).

We also provide a new angle on the older literature testing pecking-order and trade-off theories. Shyam-Sunder and Myers (1999), for example, argue that the tendency of firms to fill financing deficits with new debt rather than equity issues supports the pecking-order theory over a static trade-off model. Frank and Goyal (2003) use the same empirical methodology on an extended sample to argue in favor of the trade-off model. The analysis of managerial beliefs helps explain residual variation that is difficult to reconcile with either theory. For example, one important puzzle pointed out by Frank and Goyal (2003) is that "pecking-order behavior" best describes the capital-structure choices of large firms. However, standard pecking-order theory relates such behavior to information asymmetries, from which large firms should suffer the least. Our analysis offers one explanation: biased beliefs of managers in large firms, whose past successes make them prone to overconfidence. Instead of attempting to reconcile the Frank and Goyal (2003) findings with actual informational asymmetry (as in Lemmon and Zender (forthcoming)), we argue that perceived asymmetry drives such behavior in the subset of firms in which we observe it.

The remainder of the paper is organized as follows. In Section I, we derive empirical predictions linking managerial beliefs and past experiences to capital structure choices. Section II describes the data and the construction of our key variables. Section III describes our measures of overconfidence and early-life experiences. Section IV relates our measures to financing choices. Section V discusses alternative interpretations of our evidence and Section VI tests the robustness of our main results out-of-sample. Finally, Section VII concludes. 


\section{Testable Hypotheses}

In this section, we derive the capital-structure implications of a specific set of empirically identifiable beliefs (overconfidence) and formative past experiences (Great Depression; military service). A formal model, which focuses on overconfidence, is presented in the Online Appendix. To simplify the analysis, we allow for only two market imperfections: tax-deductibility of interest payments and financial distress costs. In allowing for these two frictions, we do not take a stand on the relative merits of pecking-order versus trade-off theories, which are both complementary to the managerial effects studied here. The assumed frictions simply serve the purpose of fixing a single optimal capital structure for a rational, value-maximizing CEO: the debt level which exactly trades off the marginal tax benefit of an additional dollar of debt against the marginal cost of financial distress (Miller (1977)). We then compare the decisions of CEOs with biased beliefs to this rational benchmark.

Though we abstract from other market frictions, including agency costs and asymmetric information, we consider how these imperfections change our predictions. Generally, our predictions are robust as long as the baseline financing model does not create boundary solutions such as full debt financing for a rational CEO. In our empirical work, we use a variety of controls and identification strategies to control for such imperfections and, hence, identify residual CEO-level variation which is unexplained by traditional theories.

We define overconfidence as the overestimation of mean returns to investment. This overestimation implies that overconfident CEOs overinvest if they have sufficient internal funds or access to riskless debt financing. However, an overconfident CEO does not necessarily overinvest, and may even underinvest, if internal or riskless financing is insufficient for the desired investment. The reason is that overconfidence also implies a (mis-)perception of the cost of external financing: Rational shareholders demand higher compensation for providing equity financing than the CEO deems appropriate. Likewise, rational creditors demand higher interest rates than the $\mathrm{CEO}$ believes are warranted as long as the CEO overestimates the cash flows available to creditors in default states. Thus, overconfident CEOs tap risky external finance only if the over-estimated investment returns are larger than the perceived financing costs.

When they do access external financing, overconfident CEOs generally perceive equity financing to be more mis-priced than risky debt. In the case of equity financing, the difference of opinions between shareholders and the CEO about future cash flows matters for all states of the world. However, in the case of risky debt, the difference of opinions matters only for default states; the extent to which the CEO overestimates cash flows in the good states, in which he is able to repay the debt obligations, is irrelevant to the interest rate. ${ }^{8}$ Thus,

\footnotetext{
${ }^{8}$ Note that the CEO may perceive debt to be more costly than equity if the probability of default is large and overconfidence is small, reversing the preference for risky debt over equity. (See the Online Appendix for more details.) Intuitively, creditors seize all of the overestimated cash flows in the event of default, but equity
} 
the equilibrium financing plan of a overconfident $\mathrm{CEO}$ will contain more risky debt than the trade-off equilibrium of a rational $\mathrm{CEO}$ with equal financing needs.

Hypothesis 1. Conditional on accessing external financing and on given financing needs (financing deficit), overconfident CEOs issue a higher portion of debt, relative to equity, than rational CEOs.

If, however, the (over-estimated) cost of external finance exceeds (over-estimated) investment returns, overconfident CEOs do not access external financing and invest only up to the limit of riskless debt finance, potentially underinvesting relative to the first best. In a dynamic setting, an overconfident manager may maintain spare riskless debt capacity in anticipation of future investments. Absent other frictions, a rational CEO, instead, always invests optimally and does not retain cash inside the firm since external finance is fairly priced and cash holdings carry a tax disadvantage. ${ }^{9}$ Thus, overconfidence can lead to debt levels which are too low relative to available tax benefits.

Hypothesis 2. Overconfident CEOs are more likely than other CEOs to issue debt conservatively relative to available tax benefits.

While the preference for debt over equity is a necessary implication of overconfidence under our baseline assumptions, debt conservatism is only a possible implication of overconfidence. However, Graham (2000), among others, finds that CEOs in large profitable firms appear to leave money on the table by choosing low debt levels. Thus, the range of parameters leading to debt conservatism may be empirically relevant, and overconfidence offers a possible explanation for an important existing empirical puzzle.

Moreover, overconfidence can potentially reconcile two seemingly contradictory empirical phenomena: the pecking order and debt conservatism. Figure 1 provides an example of an overconfident CEO having lower debt but higher leverage than under a (hypothetical) rational benchmark of financing choices. In the example, the rational and the overconfident CEO have the same investment opportunities and the same gross financing needs, but the rational CEO uses less cash financing. In the context of our reduced-form model, this is consistent with the case of both a rational and an overconfident CEO accepting an investment project with fixed scale $I$ but the overconfident CEO depleting more of his (higher) initial cash holdings. More generally, an overconfident CEO who chooses low absolute debt levels is also likely to underinvest relative to a rational CEO, given equal initial cash holdings. This effect arises in our model because debt conservatism requires perceived costs of external finance to exceed over-estimated investment returns. Even in this case, leverage, i.e., debt relative to total external capital, can be higher since equity financing is less frequent. ${ }^{10}$

holders receive only a fraction. This case is unlikely to be empirically relevant for our sample of large US firms.

${ }^{9}$ Other frictions that cause capital rationing (asymmetric information, agency costs) may distort even rational CEOs towards retaining cash. In these settings, overconfidence pushes a CEO even further toward self-sufficiency.

${ }^{10}$ Leverage can also be lower for the overconfident CEO, even if initial leverage of the two CEOs is the same 
We also consider predictable variation in CEOs' financing choices due to variation in individual traits arising from formative past experiences. Past experiences may affect behavior via two channels: changing beliefs or changing preferences. We do not formally model these effects and, hence, allow for both possibilities. Moreover, we do not distinguish between beliefs specific to the context of financing choices and more general beliefs about the self or world. To narrow the scope of our analysis and generate clear testable predictions, we require past experiences to satisfy three criteria: (1) They must be major events, (2) They must affect a significant fraction of our sample CEOs, and (3) There must be clear existing evidence linking them to later-life preferences or beliefs. We focus on two such experiences which are relevant for our sample: the Great Depression and military service, particularly during World War II. Existing evidence suggests that Depression experience discourages individuals from participating in capital markets. Hence, we would expect to observe more debt conservatism (and equity conservatism) among Depression CEOs than among their peers. Unlike overconfident CEOs, who might also display debt conservatism, Depression CEOs do not overestimate the returns arising from hand-picked investment projects; they simply have a preference for self-sufficiency. Thus, while both Depression CEOs and overconfident CEOs may display debt conservatism, the mechanism is different. Depression CEOs under-invest to avoid risky capital, but do not overinvest in bad projects when cash rich.

Hypothesis 3. CEOs who experienced the Great Depression in early adulthood access risky capital markets more conservatively than other CEOs.

Evidence from the psychology literature suggests that CEOs with a military background - and especially those with battlefield experience - are likely to have a preference for more aggressive policies, or less risk aversion. Service in the U.S. armed forces during World War II, in particular, is likely to reinforce the connection between aggressiveness and success. Unlike overconfident CEOs, military CEOs do not necessarily overestimate returns from investment. They may invest and access external capital markets optimally, but choose to lever up their companies more aggressively than other CEOs.

Hypothesis 4. CEOs with a military background maintain higher leverage than other CEOs.

In Table I, we summarize the empirical predictions of our analysis for four key capital structure outcomes: (1) the choice between public debt and equity issuance, (2) the choice to cover financing deficits using debt or equity, (3) outstanding debt relative to available interest tax deductions, and (4) market leverage.

and only the rational CEO issues any equity, if the rational CEO issues substantially more debt in absolute terms (to finance higher investment) and the optimal financing plan is leverage-increasing. 


\section{Data}

To measure CEO beliefs about future stock performance, we use several data sets, with different sample periods. Our primary sample is the data on CEOs' personal investments from Hall and Liebman (1998) and Yermack (1995). The data details the stock ownership and set of option packages - including exercise price, remaining duration, and number of underlying shares for the CEOs of 477 publicly-traded U.S. firms between 1980 and 1994, year by year. To be included in the sample, firms must appear at least four times on one of the Forbes magazine lists of largest US companies between 1984 and 1994. The sample selection is important since Frank and Goyal (2003) find systematic differences between the financing choices of small and large companies. In Section VI, we extend our analysis to smaller firms and to more recent years using data from Execucomp and Thomson Financial.

We use data on CEO age to identify birth cohort; in particular, CEOs born between 1920 and 1929 ("Depression Babies"). We also supplement the portfolio data with hand-collected information on CEO military service from Dun and Bradstreet (DEBB) and Who's Who in Finance and Industry. We classify CEOs as World War II veterans if the Who's Who or $D \mathscr{E} B$ entry specifically references World War II or if the term of service includes any years between 1941 and 1945. Similarly, we identify veterans of the Korean (1950-1953) and Vietnam (1965-1973) Wars.

As an alternative way to measure CEO characteristics, we use portrayals in the business press. We hand-collect annual data on the press coverage of sample CEOs in The Wall Street Journal, The New York Times, Business Week, Financial Times, and The Economist. We count the total number of articles referring to the CEOs using the words "confident" or "confidence;" "optimistic" or "optimism;" and "reliable," "cautious," "practical," "frugal," "conservative," or "steady." We hand-check each article to ensure that the adjectives are used to describe the $\mathrm{CEO}$ and to determine whether they are negated. We also collect detailed information on the context of each reference. For example, we record whether the article is about the CEO, the firm, or the market or industry as a whole and, if the article is about the firm, the specific policies it references (earnings, products, mergers, culture).

We merge this CEO-level data with Thomson's SDC Platinum data on U.S. new issues of common stock and convertible and non-convertible debt and preferred stock, including U.S. Rule 144A issues. Alternatively, we use COMPUSTAT cash-flow statement data to measure debt and equity issuance, including loans and other forms of private debt. Net debt issuance is the difference between long-term debt issuance (dltis) and long-term debt reduction (dltr). Net equity issuance is the difference between sales of common stock (sstk) and stock repurchases (prstkc). Long-term debt reduction and stock repurchases are set to zero if they are missing or combined with other data items. We exclude financial firms and regulated utilities (SIC codes 6000 - 6999 and 4900 - 4999). 
To measure financing needs, we construct the net financing deficit, i.e., the amount the CEO has to raise through debt or equity issues in a given firm-year to cover expenditures:

$$
F D_{t}=D I V_{t}+I_{t}+\Delta W_{t}-C_{t}
$$

$D I V$ is cash dividends; $I$ net investment (capital expenditures + increase in investments + acquisitions + other uses of funds - sale of PPE - sale of investment); ${ }^{11} \Delta W$ the change in working capital (change in operating working capital + change in cash and cash equivalents + change in current debt); ${ }^{12}$ and $C$ cash flow after interest and taxes (income before extraordinary items + depreciation and amortization + extraordinary items and discontinued operations + deferred taxes + equity in net loss (earnings) + other funds from operations + gain (loss) from sales of PPE and other investments). ${ }^{13}$ All definitions follow Frank and Goyal (2003). We use the value of book assets (at) taken at the beginning of the fiscal year to normalize debt and equity issuance and the financing deficit.

We also use COMPUSTAT to construct several firm-level control variables. We measure Q as the ratio of market value of assets to book value of assets. Market value of assets is defined as book value of total assets (at) plus market equity minus book equity. Market equity is defined as common shares outstanding (csho) times fiscal year closing price (prcc_f). Book equity is calculated as stockholders' equity (seq) [or the first available of common equity (ceq) plus preferred stock par value (pstk) or total assets (at) minus total liabilities (lt)] minus preferred stock liquidating value (pstkl) [or the first available of redemption value (pstkrv) or par value (pstk)] plus balance sheet deferred taxes and investment tax credit (txditc) when available minus post retirement assets (prba) when available. Book value of assets is total assets (at). ${ }^{14}$ We measure profitability as operating income before depreciation (oibdp) and asset tangibility as property, plants and equipment (ppent). We normalize both variables using the book value of assets at the beginning of the fiscal year. Book leverage is the quantity debt in current liabilities (dlc) plus long term debt (dltt) divided by the quantity debt in current liabilities (dlc) plus long term debt (dltt) plus common equity (ceq). We measure market leverage by replacing common equity with market equity in the definition of book leverage.

Finally, we use the "kink" variable, provided by John Graham. The construction of this variable and the associated control variables are described in Graham (2000). ${ }^{15}$ Kink is defined

\footnotetext{
${ }^{11}$ For firms reporting format codes 1 to 3 , net investment is capx + ivch + aqc + fuseo - sppe - siv; for firms reporting format code 7 , it is capx + ivch + aqc - sppe - siv - ivstch - ivaco. When items are missing or combined with other items, we code them as 0.

${ }^{12}$ For format code 1 , this is wcapc + chech + dlcch; for codes 2 and 3, - wcapc + chech - dlcch; for code 7 , - recch - invch - apalch - txach - aoloch + chech - fiao - dlcch. All items, excluding chech, are replaced with 0 when missing or combined with other items.

${ }^{13}$ For codes 1 to 3 , this is ibc + xidoc $+\mathrm{dpc}+\mathrm{txdc}+\mathrm{esubc}+\mathrm{sppiv}+$ fopo + fsrco. For code 7 , this is items $\mathrm{ibc}+\mathrm{xidoc}+\mathrm{dpc}+\mathrm{txdc}+\mathrm{esubc}+\mathrm{sppiv}+$ fopo + exre. Items are coded as 0 when missing or combined with other items.

${ }^{14}$ Definitions of Q and its components as in Fama and French (2002).

${ }^{15}$ See Table 1 for more detail. Following Graham (2000), all continuous controls in the kink regressions are
} 
as the ratio of the hypothetical level of interest at which the expected marginal tax-shield benefits of debt start to fall (numerator) to the actual amount of interest paid by the firm (denominator). It captures the amount of additional debt firms could issue before the marginal benefit of interest deductions begins to decline: When a firm is committed to low future interest payments, all of the interest payments are likely to be deducted from future profits, and the tax benefits are equal to the interest payment times the marginal corporate tax rate. As debt levels and future interest payments increase, it becomes increasingly likely that the company cannot generate enough profits to fully realize the interest tax shield. Consequently, the expected marginal tax benefit is decreasing when an additional dollar of interest payment is committed. Assuming the marginal cost of debt intersects the downward-sloping portion of the marginal benefit curve, a kink greater than 1 indicates that the firm has "left money on the table." The potential gain from adding debt increases with the kink. In this sense, high-kink firms use debt more conservatively. The kink provides a measure of the aggressiveness with which firms access debt markets which is comparable across firms and over time.

The left columns of Table II present the summary statistics for sample firms after excluding financial firms and utilities (263 firms). Panel A shows the COMPUSTAT data and the distribution across the 12 Fama and French industries. ${ }^{16}$ Panel B summarizes the variable kink and the control variables used in the kink regressions. In the latter analysis, the sample is reduced to 189 firms due to missing values of the controls required in the kink analysis. Panel $\mathrm{C}$ summarizes CEO characteristics. CEOs' age, tenure and ownership of stock and options generally serve as control variables; Depression Baby and Military Experience are our proxies for past formative experiences. In the baseline sample, the Depression indicator is equal to one for $40 \%$ of the firm-year observations. The subsample we use for our analysis of Depression effects requires the kink controls and consists of 343 CEOs, 132 of whom are Depression Babies. In the baseline sample, CEOs are coded as having military experience in $22 \%$ of firm-years. Note that we limit the sample to CEOs for whom we were able to locate a Who's Who or DEBB entry, resulting in a lower number of observations (1617). The subsample consists of 285 CEOs, 64 of whom have served in the armed forces. This restriction should minimize measurement error, though selective reporting remains a possible source of bias.

\section{Measuring Overconfidence and Formative Experiences}

Our main approach to identify CEO overconfidence is to infer CEOs' beliefs about future stock performance from their decisions to hold non-tradeable company stock options. This approach exploits CEOs' high exposure to the idiosyncratic risk of their companies: CEO compensation typically includes large grants of company stock and options. In addition, CEOs' human capital

winsorized at the $1 \%$ level.

${ }^{16}$ For definitions see http://mba.tuck.dartmouth.edu/pages/faculty/ken.french/data_library.html. 
is invested in their firms, so that bad firm performance also reduces their outside options. In order to diversify, optimizing CEOs exercise their executive options early. The exact threshold for rational exercise depends on individual wealth, risk-aversion and diversification (Hall and Murphy (2002)). CEOs who overestimate future returns of their firms, however, may hold inthe-money options beyond the rational threshold in order to personally benefit from expected stock price appreciation. Malmendier and Tate (2008) translate this logic into three measures of overconfidence using the Hall-Liebman-Yermack portfolio data. To begin, we construct the same measures, which allows us to interpret our results within the context of previous findings.

Longholder. Longholder is an indicator for all CEOs who, at any point during the sample period, hold an option until the year of expiration even though the option is at least $40 \%$ in the money entering its final year. The exercise threshold of $40 \%$ corresponds to constant relative risk aversion of 3 and $67 \%$ of wealth in company stock in the rational option exercise model of Hall and Murphy (2002). Longholder is a managerial fixed effect. The remaining measures allow for within-CEO variation.

Pre- and Post-Longholder. Post-Longholder is an indicator equal to 1 only after the CEO for the first time holds an option until expiration, provided it exceeds the $40 \%$ threshold. It allows us to isolate financing decisions after the CEO has revealed his confidence level. Pre-Longholder is equal to 1 for the other years in which Longholder is equal to 1.

Holder $6 \%$. We consider option holdings with five years remaining duration. Maintaining our prior assumptions on risk aversion and diversification, the new exercise threshold in the Hall-Murphy framework is $67 \%$ in the money. Holder 67 is binary and becomes equal to 1 once a CEO fails to exercise options with 5 years remaining duration despite a stock price increase of at least $67 \%$ since the grant date. We restrict the comparison group to CEOs who were faced with this exercise decision, but chose to exercise rather than hold. A CEO enters the sample once he has an option with 5 years remaining duration that is at least $67 \%$ in the money.

Our second approach to measure CEO overconfidence uses the perception of outsiders, as captured by CEO characterizations in the business press, instead of beliefs revealed by direct CEO choices. Our press data, described in Section II, provides the year-by-year number of articles that refer to each sample CEO. We construct an indicator of CEO confidence that compares the number of past articles using the terms $(a)$ "confident" or "confidence" or $(b)$ "optimistic" or "optimism" to the number of past articles that portray the CEO as $(c)$ not "confident," (d) not "optimistic," or $(e)$ "reliable," "cautious," "conservative," "practical," "frugal," or "steady" ( $i$ denotes the CEO):

$$
\text { TOT ALconfident } i t=\left\{\begin{array}{l}
1 \text { if } \sum_{s=1}^{t-1} a_{i s}+b_{i s}>\sum_{s=1}^{t-1} c_{i s}+d_{i s}+e_{i s} \\
0 \text { otherwise. }
\end{array}\right.
$$

We only use past media portrayal to ensure that financing policies do not affect the indicator 
directly. We also hand-check the context of the individual articles and find that few focus on financial policies: Among the 960 articles that are primarily about the firm, $53 \%$ focus on company earnings, $17 \%$ on mergers, and fewer than $5 \%$ on financial policy. We also address possible bias due to differential coverage. If, for example, there were a press bias towards positive news stories, CEOs who are often in the press would be more likely to have TOTALconfident equal to 1 . To address this possibility, we control for the total number of articles in the selected publications, aggregated over the same period as the TOTALconfident measure.

In the right half of Table II, we show firm and CEO summary statistics for the subsample of Longholder firm years. The firm characteristics are quite similar to those of the overall sample. The differences in means between firm-years with and without Longholder CEOs are typically statistically insignificant, adjusting errors for firm-level clustering. The lone exception is profitability ( 0.18 versus 0.21 ), for which we control in our regressions. In the lower part of Panel A, we see that overconfident CEOs are distributed more or less proportionally across industries, though they are overrepresented in the Chemicals and Allied Products and the Business Equipment industries, and somewhat underrepresented in Energy and Telecommunication. Panel B reveals that overconfident CEOs have higher kinks and, using the Graham (2000) industry indicators, appear to be somewhat overrepresented in the Computer Industry. In Panel $\mathrm{C}$, we see that overconfident CEOs have significantly longer tenures, with a mean of 11 years compared to 9 years in the full sample. They hold significantly less company stock, but more options than other CEOs. They are also more likely both to have served in the military and to be members of the Great Depression cohort. The sample characteristics are similar using the other measures of overconfidence. Moreover, the overconfidence measures are all positively and significantly correlated with each other: The pairwise correlations between Longholder and Holder 67, pre-Longholder, post-Longholder, and TOTALconfident, respectively, are $0.42,0.76,0.58$, and 0.09. In our regression analyses, we focus on the Longholder measure. However, we report differences in our results across measures in the text.

In Table III, we report the pairwise correlations between several firm and CEO characteristics and our two measures of formative past experiences, Depression Baby and Military Service. Depression Baby CEOs have significantly higher levels of Graham's "kink," indicating that they access debt markets conservatively. They are also significantly less likely than other CEOs to issue equity, conditional on accessing public securities markets. Military CEOs, on the other hand, do not show any aversion to debt markets and are significantly more likely to issue equity, conditional on accessing public markets. And, they appear to have higher leverage, though the correlation is not statistically significant. The directions of the effects are consistent with military experience as a proxy for (overly-) aggressive beliefs and early life experience during the Great Depression as a proxy for conservatism. It is also interesting, in light of our hypotheses, that military CEOs are significantly more likely to make acquisitions (and 
have worse operating performance). ${ }^{17}$ However, there is no correlation between the Depression cohort and merger frequency and a positive relation with ROA.

As a final step, we check whether our findings on Depression and military CEOs are consistent with outsiders' perceptions of these CEOs. Mirroring our analysis of overconfidence, we use CEOs' portrayal in the business press and the press data described in Section II. Individuals who experienced the Great Depression early in life have a preference for self-sufficiency and conservative financing choices. These preferences are likely to manifest themselves more generally in a conservative leadership style. Consistent with this story, we find a positive and significant correlation between coverage in the business press as "cautious," "practical," "reliable," "conservative," "frugal," or "steady" (variable PRESS "Cautious") and membership in the Depression cohort. Military exposure, instead, induces aggressiveness and risk-tolerance. And, indeed, we find that, military service has a significant negative correlation with PRESS "Cautious." We also test these correlations in a regression framework, controlling for differential press coverage and CEO age. Despite the imprecision of the measures, the direction of the effects remains the same, though only the negative correlation between PRESS "Cautious" and military service remains statistically significant.

\section{Managerial Traits and Capital Structure Choices}

\section{IV.A Debt vs. Equity}

Next, we test the capital structure predictions of differences in CEO traits. We begin with the choice between debt and equity. Here, only the overconfidence model makes a prediction (see Table I). Overconfident managers are reluctant to issue equity because they believe that it dilutes the claims of existing shareholders. They are also reluctant to issue risky debt because they believe that the interest rate creditors demand is too high given the distribution of future returns. On the other hand, they overestimate their financing needs because they overestimate returns to investment. Thus, overconfident CEOs may access public markets with higher or lower baseline frequencies. Conditional on accessing external financing, however, overconfident CEOs generally prefer debt to equity since debt allows current shareholders to remain the residual claimant on the firm's future cash flows. Thus, we test whether, conditional on accessing public securities markets, overconfident CEOs are less likely to issue equity.

Specification 1: Public Issues Panel A of Table IV presents the frequencies of equity and debt issues, conditional on conducting a public issue. ${ }^{18}$ Equity issues are issues of common

\footnotetext{
${ }^{17}$ The merger effect is robust to controlling for standard merger determinants like $\mathrm{Q}$ and cash flow in a logit regression.

${ }^{18} \mathrm{An}$ alternative to conditioning on issuance is to explicitly model both the decision to issue and the choice between debt and equity. We do such an analysis using a Heckman probit selection model (and the net financing
} 
or preferred stock, and debt issues are issues of non-convertible debt. Years with both a debt and an equity issue count in both categories. We find that equity issues are less frequent for overconfident CEOs under all measures. For Longholder CEOs, 31\% of firm years with public issues contain at least one equity issue. This percentage is virtually constant across Pre- and Post-Longholder years. When Longholder is 0 , instead, $42 \%$ of issue years contain an equity issue. The difference is statistically significant at the $5 \%$ level, where standard errors are adjusted for firm-level clustering. The results are stronger economically and statistically using the Holder 67 and TOTALconfident measures. Holder 67 CEOs issue equity $23 \%$ of the time, but CEOs in the comparison group issue equity $39 \%$ of the time. TOTALconfident CEOs issue equity $25 \%$ of the time, but CEOs for whom TOTALconfident is 0 issue equity $48 \%$ of the time. For both measures, the differences are significant at the $1 \%$ level, again adjusted for firm-level clustering. Overconfident CEOs also issue debt at a higher frequency than other CEOs under all measures. However, the difference is statistically significant only using the TOTALconfident measure. There are no significant differences for hybrid securities.

We test whether these cross-sectional patterns are robust to the inclusion of CEO- and firm-level controls. Panel B of Table IV presents a logit model, which uses an indicator for 'at least one equity issue during the fiscal year' as the dependent variable. We first run a baseline logit with Longholder as the only explanatory variable (Column 1). We then add portfolio controls for the incentive effects of performance-based compensation: the percentage of company stock and the number of vested options held by the CEO (Column 2). Options are scaled by shares outstanding and multiplied by 10 so that the mean is comparable to the mean of stock holdings. In Column 3, we add the standard firm controls from the capital structure literature - the natural logarithm of sales, profitability, tangibility, and Q - to capture the effects of known cross-sectional determinants of changes in leverage (Rajan and Zingales (1995)). In Column 4, we add book leverage to capture systematic differences in the ability to access debt markets. ${ }^{19}$ We then add year effects to control for the possibility that overconfident CEO-years are disproportionately clustered in cold markets for equity issuance (Column 5). Finally, in Column 6, we include the full set of firm-level controls and industry dummies from Graham (2000) as an alternative way to capture traditional capital-structure determinants. These controls (described in Panel B of Table I) include binary indicators for No Dividend, Negative Owners' Equity, Net-Operating-Loss Carryforwards, and five industry groupings, as well as continuous measures of firm size, the expected cost of financial distress (ECOST), the cyclicality of operating earnings, return on assets, the z-score, the current and quick ratios, R\&D and advertising expenditures, and Q. All controls are measured at the beginning of the fiscal year. All standard errors are adjusted for firm-level clustering.

The results confirm the pattern in the raw data. Across all specifications, Longholder CEOs

deficit and cash stock as identifying variables for the public issuance choice). Our conclusions are unaffected.

${ }^{19}$ When controlling for book leverage, we drop the few cases with book leverage greater than 1. 
are $37-49 \%$ less likely than their peers to issue equity. The estimated effects are significant at the $5 \%$ or $10 \%$ levels. Among the CEO controls, vested option holdings increase the odds of issuing equity, though the large coefficient estimate is driven by 5 outlier observations in the upper tail of the distribution. Eliminating those observations substantially decreases the coefficient without affecting the Longholder coefficient. Among the standard firm controls, only sales are consistently significant. Smaller firms are more likely to issue equity. Surprisingly, $Q$ does not seem to positively predict equity issues. As a robustness check, we control for stock returns over the prior year. We verify that past returns predict significantly higher equity issuance without materially affecting the Longholder estimate. In the specification with kink controls, firms that do not pay dividends and have more cyclical earnings appear to issue more equity, while firms with higher R\&D expenditures issue less.

We also consider the robustness of the results to alternative sets of controls. For example, we re-estimate the regression using the available controls from Gomes and Phillips (2007). ${ }^{20}$ Missing IBES data requires us to drop observations prior to 1984 . However, even in the roughly $40 \%$ smaller sample, we find qualitatively similar, though statistically insignificant, results (Longholder coefficient $=-0.395 ; p$-value $=0.188$ ). Likewise, including changes in sales, Q, profitability, or tangibility either in addition to or in lieu of the levels has little impact on the results. We also find similar results using the Holder 67 and TOTALconfident measures. The measured impact on equity issuance is statistically and economically stronger than the Longholder results in all cases but one. The one exception is the estimation including all controls and year effects with TOTALconfident as the overconfidence measure (odds ratio $=72 \% ; p$-value $=0.18)$. There are also no significant differences between the Pre- and PostLongholder portions of the Longholder effect. Finally, as in Panel A, we do not find consistently significant results when we use either debt or hybrid issuance as the dependent variable.

Overall, CEOs we classify as overconfident are less likely to issue equity conditional on accessing public securities markets, controlling for standard determinants of issuance decisions.

Specification 2: Financing Deficit We repeat the test in the standard 'financing deficit framework' of Shyam-Sunder and Myers (1999). The financing deficit measures the amount of expenditures requiring external finance. We test whether overconfident CEOs cover more of their financing deficits using debt than other CEOs. This approach is analogous to testing for fewer equity issues conditional on issuing any public security in Specification 1 above, but adds bank loans and other private sources of financing to the analysis. This approach uses data from cash flow statements and, hence, allows us to use the full sample of firm years rather than only years with a public security issuance. One immediate advantage of the larger sample is that we can include firm fixed effects, i.e., identify the impact of overconfidence separately

\footnotetext{
${ }^{20}$ Since IRRC data is unavailable for our sample period, we use the natural log of board size as an alternative governance measure. We also do not have the marginal tax rate control.
} 
from time-invariant firm effects.

Note that overconfident CEOs may raise more funds than rational CEOs (since they overestimate the returns to investment) or fewer funds (since they perceive external financing to be overpriced). Thus, rather than asking whether overconfident CEOs raise more dollars of debt or fewer dollars of equity than their peers, the appropriate test is whether the mix of external finance depends on overconfidence: Whatever the determinants of the baseline relation between debt financing and the financing deficit, do overconfident CEOs demonstrate a heightened preference for debt? Thus, our findings are unaffected by controversy over trade-off versus pecking order explanations of financing deficit regressions.

We estimate the following regression specification:

$$
\operatorname{Debt}_{i t}=\beta_{1}+\beta_{2} F D_{i t}+X_{i t}^{\prime} B_{3}+\beta_{4} \Delta_{i t}+F D_{i t} \cdot X_{i t}^{\prime} B_{5}+\beta_{6} F D_{i t} \cdot \Delta_{i t}+\epsilon_{i t}
$$

Debt is long-term debt issues minus long-term debt reduction (Net Debt Issues), normalized by beginning-of-the-year assets. FD denotes the financing deficit, as defined in Section II, and $\Delta$ is the overconfidence proxy. $X$ includes CEO- and firm-level controls. At the CEO level, we control for stock ownership and vested options. At the firm level, we use the controls from Frank and Goyal (2003): book leverage and changes in profitability, tangibility, the natural logarithm of sales, and Q. All controls are included both as level effects and interacted with $F D$. We also include firm fixed effects and their interactions with $F D$. The fixed effects allow us to separate effects we attribute to the CEO from time-invariant firm effects. In the case of Holder 67 and TOTALconfident, we also exploit variation between a CEO's overconfident and non-overconfident years. Finally, we include year effects to control for the effects of hot equity issuance markets. All standard errors account for firm-level clustering.

Table V presents the results using Longholder as the overconfidence proxy. For comparison to prior literature, Column 1 presents a baseline regression without fixed effects or controls. The coefficient of 0.729 on the financing deficit is very close to the effect estimated in ShyamSunder and Myers (1999), reflecting that our sample of large firms is more similar to their sample than to the Frank and Goyal (2003) sample. ${ }^{21}$ In Column 2, we add Longholder, its interaction with the financing deficit, firm fixed effects, and the interactions of firm fixed effects with the financing deficit. We drop the level effect of the financing deficit when including interactions of the financing deficit with firm fixed effects to avoid collinearity. Including fixed effects and their interactions with the financing deficit means we estimate separate intercepts and slopes for each individual firm. Our test identifies the impact of overconfidence on the proportion of the financing deficit covered with debt using only variation that is not confounded

\footnotetext{
${ }^{21}$ Shyam-Sunder and Myers (1999) analyze large firms, with mean assets of $\$ 953 \mathrm{~m}$ for the period 1971-1989. (Our firms are even larger, with mean assets of $\$ 5477 \mathrm{~m}$ for the period 1980-1994.) When Frank and Goyal (2003) analyze, separately, the quartile of largest firms, they find similar coefficients of 0.753 for the period 1971-1989 and of 0.675 for the period 1990-1998.
} 
by firm-specific effects. In our data, there are 35 firms in which we observe a change from an overconfident to a rational CEO, accounting for 371 of the 2,385 sample years. While a small portion of the overall variation in the data (consistent with the high value of $\mathrm{R}^{2}$ in these regressions), this variation is also the cleanest to interpret. In Column 3, we add controls for CEO stock and option ownership, and in Column 4 year fixed effects. Finally, in Column 5, we add controls for changes in sales, in Q, in profitability, and in tangibility and, in Column 6 , the lag of book leverage. ${ }^{22}$

Among the controls, deviations from (within-firm) average book leverage are negatively related to debt issues, consistent with leverage targeting. Above-average changes in Q predict less financing deficit covered with debt, consistent, for example, with market timing. More debt is used when CEOs have above average stock holdings, consistent with either incentive effects in the presence of positive information or overconfidence. Surprisingly, CEOs use significantly less debt when their option holdings are above average, though the economic magnitude is small (1-2 $\phi$ less debt per $\$ 1$ of financing deficit for a one-standard deviation increase in option holdings). In all specifications, Longholders use more debt than non-Longholder successors or predecessors in the same firm. The effect is significant at the $10 \%$ level and economically large, ranging from $32 \phi$ to $35 \phi$ more debt per $\$ 1$ of financing deficit. At the mean of the annual financing deficit $(\$ 43 \mathrm{~m})$, the estimates imply $\$ 15 \mathrm{~m}$ more in debt issuance.

The results using the TOTALconfident proxy are qualitatively similar, though weaker economically and statistically. We find no significant difference between the Pre- and PostLongholder portions of the Longholder estimate and very little impact of Holder 67, perhaps due to reduced sample size. Overall, we confirm the findings from Specification 1 using the financing-deficit framework with firm fixed effects.

\section{IV.B Internal vs. External Finance}

Overconfidence predicts not only a preference for debt over equity, but also for internal over external finance. A possible consequence is debt conservatism: Even though overconfident CEOs choose debt over equity when they access external capital markets, their preference is to forgo external markets altogether. If perceived financing costs dominate over-estimated investment returns or cash is abundant, they may not access those markets frequently enough to take full advantage of the tax benefits of debt. In other words, even if overconfident CEOs maintain higher leverage than rational CEOs, the level of debt chosen may still be conservative.

Early-life experience during the Great Depression predicts an aversion to external capital. However, unlike overconfidence, it does not predict misassessment of investment returns. Thus, debt conservatism is a necessary, not just possible consequence.

\footnotetext{
${ }^{22}$ The results are nearly identical using lagged levels of the sales, tangibility, profitability, and Q controls (as in Specification 1) rather than changes.
} 
To test these hypotheses, we use the "kink" variable of Graham (2000) to measure debt conservatism. It captures how much a firm could increase debt before the expected tax benefit begins to decline. Graham shows that firms, on average, leave money on the table by following excessively conservative debt policies. We test whether managerial traits explain a portion of the effect. We use the following regression specification:

$$
\operatorname{Kink}_{i t}=\beta_{1}+\beta_{2} \Delta_{i t}+X_{i t}^{\prime} B_{3}+\epsilon_{i t},
$$

where $\Delta$ is the managerial trait of interest and $X$ are firm- and CEO-level controls. We include the firm controls from Graham's original analysis, to ease comparison. We estimate tobit regressions because the kink is artificially bounded between 0 and 8. All standard errors are clustered at the firm level. The null hypothesis is that $\beta_{2}$ is zero; overconfidence and Depression experience predict $\beta_{2}>0$. Though these hypotheses are one-tailed, we report the results of two-tailed tests, resulting in a higher threshold for rejecting the null of no effect. We also test whether CEOs with high "kinks" simultaneously raise equity as a substitute for debt, which would falsify the overconfidence and Depression Baby hypotheses: CEOs should be both debt- and equity-conservative.

In Table VI, Panel A, we present tobit estimates of model (2). Column 1 shows a baseline regression of kink on Longholder without controls. Column 2 adds CEO-level controls and Column 3 adds the full set of firm-level controls and industry dummies from Graham (2000). ${ }^{23}$ The large number of kink controls reduces the sample to only 189 firms. Among the controls, we find some evidence that more vested option holdings are associated with lower kinks. Of Graham's 19 firm-level and industry controls, 16 have qualitatively similar effects in his and our estimations. The exceptions are negative owners' equity, the natural log of sales and advertising expense over sales, which have opposite signs. ${ }^{24}$

Longholder CEOs have higher kinks across all three specifications. The coefficient estimates are significant at the $10 \%$ level and range from 0.647 to 1.256 , representing a $16 \%$ to $32 \%$ increase in kink from its mean and an increase of 0.24 to 0.46 standard deviations.

In Columns 4 and 5, we provide parallel estimates substituting Depression Baby for Longholder. Column 4 presents the baseline regression without controls. Column 5 adds CEO age, CEO tenure, and the Graham (2000) controls. The CEO age control is particularly important in separating the effect of the Depression cohort from the effect of higher age. ${ }^{25}$ We find that Depression Babies have significantly higher levels of the kink variable. Economically, the 0.5053 increase in kink in Column 5 represents a $13 \%$ increase from the sample mean. Hence, the Depression effect is similar in magnitude to the overconfidence effect.

\footnotetext{
${ }^{23}$ Graham also includes squares of all continuous controls. Including the squares has little impact on the results: The estimated Longholder coefficient in Column 3 changes from 0.605 to 0.611 ( $\mathrm{p}=0.051$ ).

${ }^{24}$ The (untabulated) control variables are statistically significant with the exception of Negative Owners' Equity, CYCLICAL, Quick Ratio, and PPE-to-Assets.

${ }^{25}$ The results are robust to adding a quadratic term in age.
} 
Finally, Column 6 shows a specification that includes both the Longholder overconfidence measure (and portfolio controls) and Depression Baby. This specification is important given the evidence in Table II that Longholder CEOs are more often Depression Babies. We find nearly identical point estimates on both Depression Baby and Longholder, though the Longholder coefficient becomes marginally insignificant. Thus, Depression experience appears to induce a preference for self-sufficiency that is distinct from the impact of overconfidence. ${ }^{26}$

In Panel B, we test whether debt-conservative Longholder and Depression Baby CEOs are also equity-conservative - i.e., issue less equity as their firms' kinks increase - consistent with a general aversion to external finance. We tabulate the distribution of net equity issues among Longholder and among Depression Baby CEOs, separately for four different levels of kink: (i) kink $\leq 1$, (ii) $1<$ kink $\leq 3$, (iii) $3<$ kink $\leq 7$, and (iv) kink $>7$. We find that higher levels of kink are associated with less equity issuance. Both the mean and median of net equity issuance decline monotonically in kink. For Longholder CEOs, the differences in mean equity issues between groups (i) and (ii) and groups (i) and (iii) have p-values of 0.016 and 0.052 , respectively, with errors clustered at the firm level. The remaining cross-group differences are not statistically significant. For Depression CEOs, those with the highest values of the kink variable are actually net repurchasers of company equity, on average. ${ }^{27}$ Thus, both Longholder and Depression CEOs who display debt conservatism also issue equity more conservatively, implying that they rely more on internal finance. ${ }^{28}$

We perform a number of robustness checks on this evidence. One shortcoming of the tobit analysis is that we cannot include firm fixed effects without biasing the coefficient estimates due to the incidental parameters problem. To address (uncontrolled) cross-sectional differences between firms with and without Longholder (or Depression Baby) CEOs, we replicate our findings in a conditional logit framework that uses only within-firm variation for identification and an indicator for kink $>1$ as the dependent variable. Though we lose much of the information in the kink variable, our results are qualitatively similar. In the specification mirroring Column 3 , we find an odds ratio of 2.23, meaning that Longholder CEOs have more than double the odds of having kinks exceeding 1, though the estimate is not statistically significant. The Depression Baby estimate is less robust to the fixed effects specification. A possible explanation is a greater ease in matching CEO to firm preferences based on observable cohort effects than (ex ante) unobservable cognitive biases.

\footnotetext{
${ }^{26}$ We also re-run the specification in Column 6 including military service as an independent variable. Though the estimates are less powerful due to the smaller sample size, our conclusions are qualitatively unchanged. There is no significant relation between military service and kink.

${ }^{27}$ Here the cross-group difference between (i) and (iv) is significant ( $\left.\mathrm{p}=0.051\right)$; however, the differences between groups (i) and (ii) and groups (i) and (iii) are not ( $\mathrm{p}=0.122$ and $\mathrm{p}=0.194$, respectively).

${ }^{28}$ It is possible that Longholder CEOs store debt capacity in anticipation of large investments or acquisitions (thereby inducing high kinks). This explanation would be consistent with the evidence in Malmendier and Tate (2008) that overconfident CEOs do more acquisitions and prefer to finance them with cash and debt.
} 
Unlike Depression Babies, overconfident CEOs over-estimate investment returns. They do not have a general aversion to external capital, but avoid risky capital only if (1) cash is abundant or (2) perceived costs exceed (over-estimated) returns to investment. We take two additional steps to ensure that the measured aversion to debt among Longholder CEOs conforms to the full overconfidence hypothesis. First, we explore the impact of cash holdings on our estimates of the Longholder effect. We add an indicator for "Low Cash Status" and its interaction with Longholder to the regression specification in Panel A, Column 3. Low Cash Status is equal to 1 if the firm's cash stock at the beginning of the year, divided by mean industry investment, is at or below the 40th percentile in our sample. ${ }^{29}$ Mean industry investment is calculated separately for each year and each Fama-French industry shown in Panel A of Table I. We find no evidence of higher kinks among Longholder CEOs with low internal funds. Only Longholder CEOs with abundant cash have significantly higher kinks than rational CEOs. The statistical significance of the effect increases $(p$-value $=0.025)$. While the difference in kinks between Longholders with and without low cash is insignificant ( $p$-value $=$ 0.214), the result confirms that high kinks are not driven by CEOs who cannot use internal funds. Second, we analyze the relation between kink and credit-worthiness. The overconfidence hypothesis implies that debt aversion should not be found among firms with access to riskless debt financing, for which there is no disagreement about the appropriate interest rate. We use the S\&P Long-Term Domestic Issuer Credit Rating to split the sample into thirds: firm-years with $\mathrm{A}+$ ratings or better are in the highest third, and firm-years with BBB ratings or worse are in the lowest third. We drop firms with missing credit ratings. Repeating the tobit analysis of Table VI, Panel A, on each subsample, we find that the effect is concentrated in the middle third: the coefficients and $p$-values for Longholder in the Column 3 specification are 0.489 (0.32), 0.823 (0.018), and $0.412(0.178)$ for low, middle, and high credit ratings. The lack of an effect among the highest-rated firms confirms that Longholder CEOs are not reluctant to raise (nearly) riskless debt. Moreover, the weak effect among the lowest-rated firms suggests that high kinks among Longholder CEOs are not an artifact of systematically worse credit ratings.

Finally, we re-estimate our regressions using the alternative proxies for overconfidence. We find similar results using Holder 67 and little difference across the Pre- and Post-Longholder portions of the Longholder measure. TOTALconfident CEOs, however, have lower kinks than other CEOs, though the result is not robust to the fixed effects logit specification. Given our earlier finding in Table III that only TOTALconfident CEOs are associated with a significantly higher probability of public debt issuance, one possible interpretation for the difference in results is that, among overconfident CEOs, the press is most likely to identify the ones who demonstrate their beliefs by over-investing, thereby requiring higher external finance.

\footnotetext{
${ }^{29}$ The results are robust to using other cutoffs, such as the 25 th or the 30 th percentile, and alternative proxies for "expected volume of investment," such as prior-year averages.
} 


\section{IV.C Leverage}

Recent research argues that there are large unexplained time-invariant effects in leverage (Lemmon et al. (2008)). One interesting question is whether managerial traits, such as overconfidence, can explain these differences across firms: Do differences in financing (or changes in leverage) accumulate into differences in capital structures (levels of leverage)? In the context of overconfidence, this is an empirical question since the theoretical prediction could go either way, depending on the relation between over-estimated investment returns, cash holdings, and perceived financing costs. In the context of military experience, however, we have a clear prediction of higher leverage.

Unfortunately, it is difficult to assess causality in cross-sectional leverage regressions and, specifically, to determine whether the effect is due to the manager or to the firm. For example, firms that leverage more aggressively may also be attractive places for overconfident CEOs to work. Alternatively, overconfident CEOs may be attracted by the spare debt capacity in low-leverage firms. In other words, selection effects might obscure the true impact of individual CEOs. In order to obtain identification, we follow an approach similar to Bertrand and Schoar (2003) and compare leverage under different CEOs operating the same firm:

$$
\text { Leverage }_{i t}=\beta_{1}+X_{i t}^{\prime} B_{2}+\beta_{3} \Delta_{i t}+\epsilon_{i t}
$$

where Leverage is end-of-fiscal-year market leverage, $X$ is a vector of firm and CEO control variables, and $\Delta$ is the managerial trait of interest.

We begin by estimating two baseline regressions for comparison with existing literature. In Column 1 of Table VII, we estimate a pooled regression, including our standard set of firmlevel controls: profitability, tangibility, size, Q, and the financing deficit. Standard errors are clustered at the firm level. The controls explain $34 \%$ of the variation in leverage and have the typical directional effects: size (+), profitability (-), tangibility $(+), \mathrm{Q}(-)$, and financing deficit $(+) .{ }^{30}$ In Column 2, we add firm fixed effects. Consistent with Lemmon et al. (2008), we find that adding firm effects more than doubles the $R^{2}$ of the regression. Among the controls, only tangibility loses explanatory power when estimated using within-firm variation.

Next, we test whether differences in managerial confidence levels can explain remaining within-firm variation in leverage. Adding Longholder (Column 3), we find that overconfident CEOs maintain significantly higher leverage than their predecessors or successors. The percentage of explained within-firm variation increases from $11 \%$ to $12 \%$. The effect is robust to the inclusion of several important controls: In Column 4, we add five lags of stock returns to capture the impact of stock prices changes on leverage ratios (Welch (2004)) $)^{31}$ and on option

\footnotetext{
${ }^{30}$ We include financing deficit for consistency with our earlier specifications. It is indeed significant. However, the Longholder effect does not depend upon its inclusion.

${ }^{31}$ We do not include contemporaneous returns due to endogeneity concerns. However, the results are robust to this additional control.
} 
exercise. As expected, stock returns have a significantly negative impact on leverage. The effect decays in the length of the lag, with the fifth lag being insignificant. Including stock returns also eliminates the predictive power of $\mathrm{Q}$ while improving the $R^{2}$ of the regression. In Column 5, we add our standard CEO controls for stock and option holdings. If CEOs have private information then these controls capture variation in CEOs' concern over diluting their personal equity stakes through new issues. We also add year effects and CEO tenure and its interaction with Longholder to the regression. We find a negative coefficient on the interaction of tenure with Longholder, which may reflect learning - Longholder CEOs learn to issue risky capital more appropriately as their tenures increase - but may also reflect a tendency of Longholder CEOs to exhaust their firms' debt capacities early in their tenures and subsequently finance desired (over-)investment using equity.

The effect of Longholder on leverage is large. In the Column 4 specification, for example, replacing a rational CEO with an overconfident one increases firm leverage by $20 \%$ of a standard deviation or, alternatively, by $15 \%$ from its mean level. The true CEO effect may be even larger since we are conservative in separating out time-invariant firm effects: some of the effects we attribute to the firm may actually reflect the influence of past and current CEOs. In particular, our estimates of $\beta_{3}$ do not exploit any information from firms with only a single (overconfident) CEO during our sample period; however, such long-tenured CEOs may have the largest impacts on their firms' capital structures.

Next, we test whether CEOs with a military background pursue more aggressive financial policies. In Column 6, we find that military CEOs choose higher leverage than their predecessors or successors. Economically, the effect is smaller than the impact of overconfidence, increasing leverage by $17 \%$ of a standard deviation or, alternatively, by $13 \%$ from its mean. Statistically, the baseline effect of military experience is significant at the $10 \%$ level after clustering at the firm level. In Column 7, we add our standard set of firm-level controls - profitability, tangibility, firm size, Q, and the financing deficit - and the relevant CEO-level controls, age and tenure. The coefficient of past military service is virtually unaffected. In Column 8, we refine our measure of military experience by separating World War II veterans, who are more likely to have had combat exposure, from other military CEOs. ${ }^{32}$ We find that, indeed, the impact of military service on leverage choices comes primarily from World War II veterans. Among this group, the chosen leverage is $25 \%$ higher than the sample mean, and the difference to other military experience is significant at the $5 \%$ level. This result also helps to address the self-selection explanation, under which aggressive or risk-tolerant individuals choose to serve in the military (and later take more aggressive managerial decisions), as involuntary service

\footnotetext{
${ }^{32}$ Alternatively, we code "combat exposure" as including World War II, the Korean, and the Vietnam Wars. The results are the same: we find a positive and significant effect on leverage, controlling for Military Experience. However, the coefficient appears to be driven by World War II. If we include separate dummies for the 12 Korean War veterans and 8 Vietnam War veterans in our sample, we find insignificant coefficients.
} 
was common during World War II.

Finally, in Column 9, we include Military Experience and World War II Veteran with the Longholder overconfidence measure and the union of relevant controls. Despite the reduced sample size, both the Longholder and World War II Veteran variables remain positive and significant, suggesting that they capture different subsets of CEOs or traits. ${ }^{33}$

We perform a number of additional robustness checks, using alternative variable definitions, regression specifications, and methodology. First, we consider book rather than market leverage as the dependent variable. The results are qualitatively similar though statistically weaker. For example, the coefficient estimate on Longholder is 0.042 with a t-statistic of 1.51 in the Column 5 specification. One potential reason for the discrepancy is that book equity - as a historical accounting measure - has only a noisy relation to the economic quantity of interest, the value of shareholders' cash flow claims. We also find similar results using an alternative methodology inspired by Baker and Wurgler (2003), i .e., measuring the relation between the change in leverage and the number of overconfident sample CEO years (or, alternatively, "external finance weighted" overconfidence). Finally, we find similar results using the TOTALconfident proxy, with a few notable differences. First, the relation with the overconfidence proxy is stronger in the cross-section than within firms. Second, the relation is stronger when we remove within-CEO variation. Finally, the effect is typically strongest using book, rather than market, leverage as the dependent variable.

Overall, our results support the hypothesis that managerial traits help to explain variation in capital structure that cannot be explained by time-invariant firm differences or variation in traditional capital-structure determinants. Though we cannot identify the effect econometrically (due to joint determination), the evidence suggests that managerial factors account at least partially for the time-invariant, firm-specific component of leverage uncovered in recent empirical studies. The results are also consistent with predictions of the overconfidence hypothesis: overconfident CEOs view equity financing as a last resort, resulting in measurable differences in firm leverage ratios compared to their rational predecessors or successors.

\section{Alternative Interpretations}

We consider several alternative interpretations of our main measure of overconfidence, late option exercise. We exclude several explanations that have no link to capital-structure decisions or have little or no bearing on the press measure. For example, personal taxes, board pressure and procrastination are potential explanations for late option exercise, but have no plausible effect on CEOs' portrayal in the business press.

\footnotetext{
${ }^{33}$ For completeness, we also re-run the Column 9 specification including Depression Baby, even though we do not have a theoretical prediction. There is no significant relation with leverage.
} 
Dilution. CEOs with extensive holdings of company stock and options may want to avoid diluting those holdings with additional equity issues. Graham and Harvey (2001), for example, report that earnings-per-share dilution is a primary consideration in stock issuance decisions. While this interpretation is unlikely to affect our press measure, we address the concern by controlling directly for the level of CEO stock and option holdings in all of our estimations. These controls capture CEO incentives to avoid dilutionary equity issuance based on their own portfolio compositions. Our measures capture, instead, the timing of option exercise, not the level of holdings. We also control for leverage and credit rating since CEOs of firms near financial distress may rationally worry more about dilution due to debt overhang. In addition, note that perceived dilution is exactly the mechanism that causes overconfident CEOs to avoid issuing equity. Thus, it is important to distinguish overconfidence from real information.

Inside Information. A CEO may choose not to exercise in-the-money options because of positive private information about future earnings. In this case, holding company stock options is a profitable investment until outsiders learn the information. Moreover, CEOs with such information may justifiably exude "confidence" and "optimism" to the business press. In this case, our results would support the traditional information-based pecking-order theory. The key difference from overconfidence is whether CEOs' beliefs are correct.

We check whether CEOs earn positive abnormal returns from holding options. We find that Longholder CEOs would earn greater profits on average by exercising 1, 2, 3, or 4 years earlier and investing in the S\&P 500 for the remainder of the options' durations. ${ }^{34}$ We find similar evidence for the Holder 67 measure. This evidence suggests that the average Longholder or Holder $67 \mathrm{CEO}$ does not have positive inside information.

Signalling. The apparent absence of inside information casts doubt on rational signalling as an interpretation of our measures. If late option exercise and bold statements to the press are meant to signal strong future stock price performance, those signals seem ineffective: CEOs who send them are the least likely to issue equity and their stock does not display positive abnormal performance. It is possible, though, that investors would expect even worse future performance in the absence of option-holding and strong statements in the press, leading to even less equity issuance. Our findings using the Post-Longholder measure cast doubt on this interpretation. If private information drives managerial financing preferences for debt over equity and delayed option exercise (and press coverage) signals that information to the market, we would expect a weaker impact of past 'signals.' Instead, we find little difference between the relation of past and contemporaneous late exercise to financing choices.

Risk Tolerance. CEOs may hold options longer due to a higher willingness to take risk. Risk-tolerant CEOs may also appear more "confident" and "optimistic" and less "cautious," "conservative," "practical," "reliable," or "steady" to business reporters. In addition, bankruptcy is less of a deterrent to debt issuance for risk-seeking CEOs. However, risk tolerance

\footnotetext{
${ }^{34}$ See Malmendier and Tate (2004) for detailed tables.
} 
does not predict aversion to external financing. Thus, our debt conservatism results in Section IV.B are difficult to reconcile with this story.

Thus, each of these interpretations is difficult to reconcile with some of the evidence. Overestimation of future performance, instead, is consistent with all of our findings. The main insight of the paper, however, is independent of this interpretation: systematic and measurable differences in CEO beliefs and traits predict systematic differences in financial policies.

\section{Robustness: Extension to 2007}

As a final step, we extend our analysis beyond the 1980-1994 Hall-Liebman data. We gather insider trading data from Thomson Financial and personal portfolio data from Compustat's Execucomp database. The Thomson data contain detailed information on CEO option exercise. Execucomp includes annual snapshots of aggregate CEO stock and option holdings, which are needed as controls in the overconfidence analysis. The merged data covers S\&P 1500 firms from 1992-2007 and includes smaller firms than our main sample. As shown in the summary statistics in Appendix Table A1, the median firm is roughly half as large. Generally, the sample characteristics differ in the expected direction: asset tangibility is smaller, $\mathrm{Q}$ is higher, and the fraction of non-dividend payers is higher.

One immediate observation is that the extended data is not suitable to analyze early life shocks from the Great Depression or service in World War II. Due to age and retirement, the fraction of Depression CEOs declines precipitously after 1995. Overall, only 3\% of firmyears have a Depression CEO. The fraction of World War II veterans declines similarly. After supplementing the data with hand-collected information on military service through 2003, we find that less than $1 \%$ of firm-years have a World War II veteran as CEO. ${ }^{35}$

We use the data to construct several alternative overconfidence measures which correspond as closely as possible to our core measures based on late option exercise (Section III). Below we describe the measures and their limitations relative to our original measures:

Longholder_Exec. Our core measure of overconfidence exploits package-level information about strike prices and remaining duration to identify late option exercise. Execucomp contains such information for all CEO option packages outstanding at the end of each fiscal year, beginning in 2006. Using this data, we exactly replicate the Longholder measure. The drawback of this measure is the limited availability. In particular, the short time series includes

\footnotetext{
${ }^{35}$ We re-analyze the link between military experience and leverage in the later sample for veterans of the Korean or Vietnam Wars and for all veterans. The results confirm our earlier finding that the link between military experience and leverage is specific to WWII veterans. One interpretation is that success or failure of the military experience matter for later-life attitudes. Though these experiences vary at the individual level, World War II veterans are more likely to have had a victorious personal experience and may be more likely to interpret individual failures as nevertheless contributing to a major collective victory.
} 
very few $\mathrm{CEO}$ changes in a given firm, precluding fixed-effects analyses, and shows the exercise decisions of newly hired CEOs for at most 2 years.

Longholder_CJRS. For years prior to 2006, Execucomp contains fewer details about the new options granted (total number and value) and only aggregated information on the number and value of exercised as well as outstanding options. Package-level strike prices and remaining duration, are not available. ${ }^{36}$ Thus, the data does not allow us to determine whether a CEO held an option to expiration as required by the Longholder measure and how much it was in the money. The closest approximation feasible with the older Execucomp data is the approach proposed by Campbell et al. (2009) and Hirshleifer et al. (2010): They use the aggregate data to calculate average strike prices and, therefore, the average moneyness of the options, assuming the options are not underwater. A CEO is then classified as overconfident for all sample years after he first holds exercisable options that are, on average, at least $67 \%$ in the money at the end of a fiscal year, mirroring our Holder 67 measure. In addition, the CEO must fail to exercise such options at least one additional time during the sample period. Under this approach, it is not possible to impose a restriction on remaining option duration (though such a restriction is theoretically required) since the data does not allow inferences about remaining duration, even on average.

Longholder_Thomson (_Fill). Thomson Financial contains transaction-level data, including the expiration date and strike price of each exercised CEO option from 1996 to the present. Thus, it should be possible to replicate the original Longholder measure constructed from annual snapshots of CEO option-holdings. To do so, we follow a procedure similar to Otto (2009) and classify a CEO as overconfident if the CEO exercises an option in the final year of its duration and the option is at least $40 \%$ in-the-money one year prior to its expiration date. However, we find that the insider filings, particularly for derivative transactions, are noisy. We must drop more than $25 \%$ of CEO option exercises due to cleanse codes which indicate poor data quality, absence of required data items (strike prices or expiration dates), and obvious reporting mistakes (e.g. transaction date after the expiration date). These issues also raise doubts about how to classify CEOs for whom we do not observe (usable) exercise information, particularly since we know from the Execucomp snapshots that most of these CEOs have options. We consider two possibilities: (1) we include only CEOs for whom we observe at least one Thomson option exercise (Longholder_Thomson) and (2) we include all Execucomp CEOs (Longholder_Thomson_Fill). The two variables differ only in the comparison group; the set of CEOs classified as overconfident is identical. We provide additional details on constructing the Longholder_Thomson measures in the Appendix.

\footnotetext{
${ }^{36}$ In principle, the data allows one to track new grants over time and attempt to match changes in aggregate option holdings back to their original annual grant "package" using, e.g., a first-in first-out allocation rule. This approach is noisy and reduces the usable sample period to a few years. Instead, we construct an alternative measure using Thomson transaction-level data which contains explicit information on the expiration dates and strike prices of exercised (and expiring) options.
} 
In Appendix Table A1, under the columns denoted with (II), (III), and (IV) we present summary statistics of overconfident CEO-years under each of the measures. The most pronounced differences are in firm size: Longholder_Exec CEOs operate firms with more assets, though the difference also reflects the later sample years. They also have the highest kinks.

In Table A2, we present additional statistics and correlations of the new measures to assess how well they replicate our main portfolio-based overconfidence measures. Panel A shows the $\%$ of CEOs classified as overconfident. As anticipated, Longholder_Exec, which is identical in definition to the original Longholder measure, provides the best match to Longholder, with both classifying roughly $20 \%$ of CEOs as overconfident. For the other measures, we see wide variation, ranging from $32 \%$ to $54 \%$. Panel B shows the pairwise correlations between the different measures. In all cases, we find positive and significant correlations. Longholder_Thomson (_Fill) should exactly match Longholder_Exec in CEO-years for which both are defined; however, we find a correlation of only 0.44 (0.48). The correlation of Longholder_CJRS with Longholder_Exec is even lower (0.22). The latter is less surprising since Longholder_CJRS differs from the other measures in relying on option moneyness to determine CEO beliefs, rather than remaining option duration at exercise.

The lower correlation and difference in definition raise the concern that Longholder_CJRS may mix information about CEO beliefs with information about firm performance: Rather than capturing a CEO's overestimation of future performance it might (also) capture good past performance. Avoiding such a confound is crucially important in our context since overconfidence makes opposite predictions for financing choices to strong stock performance. To quantify this concern, we calculate the pairwise correlations of Longholder_CJRS with five lags of annual stock returns (excluding dividends). We find that Longholder_CJRS is indeed significantly positively correlated with each lag of returns. The correlations between Longholder_Exec and lags of returns, instead, are smaller by an order of magnitude and insignificant for three of the five horizons.

Overall, our analysis suggests (1) Longholder_Exec is the best candidate to replicate the Malmendier and Tate (2008) overconfident measures (though its implementability suffers from the very short sample period) and (2) the other measures capture information about CEO beliefs, but are noisier and influenced by other systematic factors (performance).

The key (unambiguous) prediction of the overconfidence theory is that overconfident CEOs prefer risky debt to equity, conditional on accessing external capital (Hypothesis 1). Our analysis of public security issuance tests this prediction using (in part) cross-sectional variation across CEOs. Since such variation is required to employ the Longholder_Exec measure, we focus on this test to determine the robustness of our key results in later firm years and among the broader cross-section of firms.

We report the results in Table A3. In a univariate specification (Panel A, Column 1), Longholder_Exec CEOs are roughly $45 \%$ less likely to issue equity, significant at the $10 \%$ level. 
The result is stronger both economically and statistically using the various sets of controls from Section IV.A.

We also re-estimate our regressions using the Longholder_CJRS and Longholder_Thomson (_Fill) measures. Using either Thomson-based measure, we confirm our basic results (though the estimates are typically smaller economically). Using the Longholder_CJRS measure, the results depend crucially on the set of controls. In the univariate setting, the estimate is positive and significant. However, once we add the controls for past stock performance, the estimate becomes negative and significant. Strong past stock performance predicts heightened equity issuance. Since Longholder_CJRS is positively correlated with past performance, it picks up this effect. The negative overconfidence effect emerges only with careful performance controls.

Our results suggest that the impact of overconfidence on financing choices is likely to generalize over time and across firms. The results demonstrate both the promise and potential pitfalls of using common data sources to measure late option exercise over the 1995-2005 time period.

\section{Conclusion}

We provide evidence that managers' beliefs and early-life experiences significantly affect financial policies, above and beyond traditional market-, industry-, and firm-level determinants of capital structure. We begin by using personal portfolio choices of CEOs to measure their beliefs about the future performance of their own companies. We focus on CEOs who persistently exercise their executive stock options late relative to a rational diversification benchmark. We consider several interpretations of such behavior - including positive inside information - and show that it is most consistent with CEO overconfidence. We also verify our measure of revealed beliefs by confirming that such CEOs are disproportionately characterized by the business press as "confident" or "optimistic," rather than "reliable," "cautious," "practical," "conservative," "frugal," or "steady."

This form of belief makes specific capital structure predictions: Overconfident CEOs overestimate future cash flows and, therefore, perceive external financing - and particularly equity - to be unduly costly. Thus, they prefer internal financing over external capital markets and, conditional on raising risky capital, debt over equity. We find strong evidence that, conditional on accessing public securities markets, overconfident CEOs are less likely to issue equity than other CEOs. We also find that, to cover an additional dollar of external financing deficit, overconfident CEOs issue about 33 cents more debt than their peers. Managerial overconfidence is also positively related to debt conservatism, measured using the "kink" variable from Graham (2000). This debt conservatism is not driven by an increased propensity to issue equity. Instead, overconfident CEOs who are debt-conservative are also equity conservative and rely excessively on internal funds. Finally, overconfident managers choose higher leverage ratios 
than predecessors or successors in their firms.

Second, we consider early-life experiences which are likely to shape beliefs and choices later in life. Guided by prior psychology and management literature, we focus on two major formative experiences which affect our sample CEOs: growing up during the Great Depression and serving in the military. We find that CEOs who experience the Great Depression early in life display a heightened reluctance to access external capital markets. World War II CEOs, on the other hand, choose more aggressive corporate policies, including higher leverage ratios. The effects are distinct from the impact of overconfidence on financial decisions. Though the specific shocks which guide belief formation may differ in other samples of CEOs, our methodology for identifying those shocks is easily generalized.

Our results have several implications. First, our findings help to explain the strong timeinvariant component of firm capital structure identified in recent studies. Though our identification strategy requires us to establish the impact of managerial beliefs using within-firm variation, the significance of our measures suggests that variation in managerial beliefs may account for a significant portion of the (co-determined) between-firm variation. Managerial beliefs may be particularly important in firms with long-serving managers, family ownership, or a preference for hiring managers with a particular "style."

Second, our results have distinct implications for contracting practices and organizational design. To the degree that boards do not anticipate or desire bias-driven policies, standard incentives, such as stock- and option-based compensation, are unlikely to offset fully the effects of managerial overconfidence on investment and financing decisions. Biased managers believe they are choosing value-maximizing policies, and boards may need to use different tools, such as cash dividend payment and debt overhang, to constrain overconfident CEOs. Similarly, financial incentives will be miscalibrated if they do not account for financial conservatism or financial aggressiveness arising from the CEO's past experiences.

Third, our findings on the financial decision-making of Depression and military CEOs provide evidence that major personal events can have a life-long impact on risk attitudes and choices. Macroeconomic shocks, such as the current financial crisis, are likely to have not only an immediate impact on corporate financial policies (e.g. through de-leveraging and a shift toward self-sufficiency), but also an impact on future policies as today's young investors, who are being introduced to financial markets during a time of crisis, become the next generation of corporate leaders. Thus, the Depression Baby results not only document a pattern of historical interest, but also suggest how financial choices may play out over the coming decades.

Finally, exposure to a military environment may affect corporate decision-making more broadly than just financial policy. For example, military CEOs may implement a more command-based corporate culture. An interesting topic for future research is to test whether CEOs with military experience create a more hierarchical structure in their firms. 


\section{References}

[1] Alicke, Mark D., M.L. Klotz, David L. Breitenbecher, Tricia J. Yurak et al., 1995, Personal contact, individuation, and the better-than-average effect, Journal of Personality and Social Psychology 68, 804-825.

[2] Baker, Malcolm, and Jeffrey Wurgler, 2002, Market timing and capital structure, Journal of Finance 57, 1-32.

[3] Baker, Malcolm, Richard Ruback, and Jeffrey Wurgler, 2007. Behavioral Corporate Finance, in Espen Eckbo, ed.: Handbook of Corporate Finance: Empirical Corporate Finance (Elsevier/North-Holland).

[4] Baker, Malcolm, Jeremy C. Stein, and Jeffrey Wurgler, 2003, When does the market matter? Stock prices and the investment of equity-dependent firms, Quarterly Journal of Economics 118, 969-1005.

[5] Ben-David, Itzak, John Graham, and Campbell Harvey, 2007, Managerial Overconfidence and Corporate Policies, Working Paper.

[6] Berkowitz, Leonard and Anthony Lepage, 1967, Weapons as aggression-eliciting stimuli, Journal of Personality and Social Psychology 7, 202-207.

[7] Bertrand, Marianne, and Antoinette Schoar, 2003, Managing with style: The effect of managers on firm policies, Quarterly Journal of Economics 118, 1169-1208.

[8] Billett, Matthew T., and Yiming Qian, 2008, Evidence of self-attribution bias from frequent acquirers, Management Science 54, 1037-1051.

[9] Camerer, C., and D. Lovallo, 1999, Overconfidence and excess entry: an experimental approach, American Economic Review 89, 306-318.

[10] Campbell, T. Colin, Shane. A. Johnson, Jessica Rutherhford, and Brooke Stanley, 2009, CEO confidence and forced turnover, Working Paper.

[11] Chevalier, Judith and Glenn Ellison, 1999, Are some mutual fund managers better than others? Cross-sectional patterns in behavior and performance, Journal of Finance 54, 875-899.

[12] Donaldson, Gordon, 1990, Voluntary restructuring: The case of General Mills, Journal of Financial Economics 27, 117-141.

[13] Elder, Glen, 1986, Military times and turning points in men's lives, Developmental Psychology 22, 233-45.

[14] Elder, Glen, 1998, Children of the Great Depression, 25th Anniversary Edition, Westview Press, Boulder, CO.

[15] Elder, Glen, and Elisabeth Clipp, 1989, Combat experience and emotional health: Impairment and resilience in later life, Journal of Personality 57, 311-341. 
[16] Elder, Glen, C. Gimbel, and R. Ivie, 1991, Turning points in life: The case of military service and war, Military Psychology 3, 215-231.

[17] Frank, Murray Z., and Vidham K. Goyal, 2003, Testing the pecking order theory of capital structure, Journal of Financial Economics 67, 217-248.

[18] Frank, Murray Z., and Vidham K. Goyal, 2007a, Trade-off and pecking order theories of debt, in Espen Eckbo, ed.: Handbook of Corporate Finance: Empirical Corporate Finance (Elsevier/North-Holland).

[19] Frank, Murray Z., and Vidham K. Goyal, 2007b, Corporate leverage: How much do managers really matter? Working Paper.

[20] Goel, Anand, and Anjan V. Thakor, forthcoming, Overconfidence, CEO selection, and corporate governance, Journal of Finance.

[21] Gomes, Armando, and Gordon Phillips, 2007, Why do public firms issue private and public securities? Working Paper.

[22] Graham, John R., 2000, How big are the tax benefits of debt? Journal of Finance 5, 1901-1942.

[23] Graham, John R., and Campbell R. Harvey, 2001, The theory and practice of corporate finance: evidence from the field, Journal of Financial Economics, 60, 187-243.

[24] Graham, John, and Krishna Narasimhan, 2004, Corporate survival and managerial experiences during the Great Depression, Working Paper.

[25] Hackbarth, Dirk, forthcoming, Managerial traits and capital structure decisions, Journal of Financial and Quantitative Analysis.

[26] Hall, Brian J., and Jeffrey B. Liebman, 1998, Are CEOs really paid like bureaucrats? Quarterly Journal of Economics 113, 653-691.

[27] Hall, Brian J., and Kevin J. Murphy, 2002, Stock options for undiversified executives, Journal of Accounting and Economics 33, 3-42.

[28] Heaton, J.B., 2002, Managerial optimism and corporate finance, Financial Management $31,33-45$.

[29] Hechinger, J., 1998, Heard in New England: SLI's chief blasts analyst as firm puts off a big stock offering, Wall Street Journal, Jun 3, p. NE2.

[30] Hietala, Pekka, Steven Kaplan, and David Robinson, 2003. What is the price of hubris? Using takeover battles to infer overpayments and synergies, Financial Management 32, $1-32$.

[31] Hirshleifer, David, Siew Hong Teoh, and Angie Low, 2010, Are overconfident CEOs better innovators? Working Paper. 
[32] Holderness, Clifford G., Randall S. Kroszner, and Dennis P. Sheehan, 1999, Were the good old days that good? changes in managerial stock ownership since the Great Depression, Journal of Finance 54, 435-69.

[33] Jensen, Michael C., and William H. Meckling, 1976, The theory of the firm: managerial behavior, agency costs, and ownership structure, Journal of Financial Economics 3, 305360 .

[34] Kidd, John B., 1970, The utilization of subjective probabilities in production planning, Acta Psychologica 34, 338-347.

[35] Killgore, William D.S., Dave I. Cotting, Jeffrey L. Thomas, Anthony L. Cox, Dennis McGurk, Alexander H. Vo, Carl A. Castro, and Charles W. Hoge, 2008, Combat invincibility: Violent combat experiences are associated with increased risk-taking propensity following deployment, Journal of Psychiatric Research 42, 1112-1121.

[36] Lambert, Richard A., David F. Larcker, and Robert E. Verrecchia, 1991, Portfolio considerations in valuing executive compensation, Journal of Accounting Research 29 (1), 129-149.

[37] Landier, Augustin, and David Thesmar, forthcoming, Contracting with optimistic entrepreneurs: Theory and evidence, Review of Financial Studies.

[38] Langer, Ellen J., 1975, The illusion of control, Journal of Personality and Social Psychology $32,311-328$.

[39] Larwood, L., and W. Whittaker, 1977, Managerial myopia: self-serving biases in organizational planning, Journal of Applied Psychology 62, 94-198.

[40] Lemmon, Michael and Jaime Zender, forthcoming, Debt capacity and tests of capital structure, Journal of Financial and Quantitative Analysis.

[41] Lemmon, Michael, Michael Roberts, and Jaime Zender, 2008, Back to the beginning: Persistence and the cross-sectional distribution of capital structure, Journal of Finance $63,1575-1608$.

[42] Lowe, Robert A., and Arvids A. Ziedonis, 2006, Overoptimism and the performance of entrepreneurial firms, Management Science 52, 173-186.

[43] Malmendier, Ulrike, and Stefan Nagel, 2008, Depression babies: Do macroeconomic experiences affect risk-taking? Working Paper.

[44] Malmendier, Ulrike, and Geoffrey A. Tate, 2005, CEO overconfidence and corporate investment, Journal of Finance 60, 2660-2700.

[45] Malmendier, Ulrike, and Geoffrey A. Tate, 2004, Who makes acquisitions? CEO overconfidence and the market's reaction, NBER Working Paper 10813.

[46] Malmendier, Ulrike, and Geoffrey A. Tate, 2008, Who makes acquisitions? CEO overconfidence and the market's reaction, Journal of Financial Economics 89, 20-43. 
[47] March, J.G., and Z. Shapira, 1987, Managerial perspectives on risk and risk taking, Management Science 33, 1404-1418.

[48] Miller, Merton H., 1977, Debt and taxes, Journal of Finance 32, 261-275.

[49] Miller, Dale T., and M. Ross, 1975, Self-serving biases in the attribution of causality: fact or fiction? Psychological Bulletin 82, 213-225.

[50] Millman, Gregory J., 2001, Managing up the CFO and the board, Financial Executive 17, 24-26.

[51] Modigliani, Franco, and Merton H. Miller, 1958, The cost of capital, corporate finance, and the theory of investment, American Economic Review 48, 655-669.

[52] Moore, P.G., 1977, The manager's struggle with uncertainty, Journal of The Royal Statistical Society Series A 149, 129-165.

[53] Myers, Stewart C., 1984, The capital structure puzzle, Journal of Finance 39, 575-592.

[54] Myers, Stewart C., and Nicholas S. Majluf, 1984, Corporate financing and investment decisions when firms have information that investors do not have, Journal of Financial Economics 13, 187-221.

[55] Ofek, Eli, and David Yermack, 2000, Taking stock: equity-based compensation and the evolution of managerial ownership, Journal of Finance 55, 1367-1384.

[56] Otto, Clemens A., 2009, CEO optimism and incentive compensation, Working Paper.

[57] Oyer, Paul, 2008, The making of an investment banker: Stock market shocks, career choice, and lifetime income, Journal of Finance 63, 2601-2628.

[58] Rajan, R.G., and L. Zingales, 1995, What do we know about capital structure? Some evidence from international data, Journal of Finance 50, 1421-1460.

[59] Roll, R., 1986, The hubris hypothesis of corporate takeovers, Journal of Business 59, 197-216.

[60] Schoar, A., 2007, CEO careers and style, Working Paper.

[61] Shyam-Sunder, L., and S.C. Myers, 1999, Testing static trade-off against pecking order models of capital structure, Journal of Financial Economics 51, 219-244.

[62] Wansink, Brian, Collin R. Payne, and Koert van Ittersum, 2008, Profiling the heroic leader: Empirical lessons from combat-decorated veterans of World War II, Leadership Quarterly 19, 547-555.

[63] Weisbach, M., 1995, CEO Turnover and the firm's investment decisions, Journal of Financial Economics, 37, 159-188.

[64] Weinstein, N., 1980, Unrealistic optimism about future life events, Journal of Personality and Social Psychology 39, 806-820. 
[65] Welch, Ivo, 2004, Capital structure and stock returns, Journal of Political Economy 112, 106-131.

[66] Whitford, D., 1999, Jesse shakes the money tree, Fortune 139, Iss. 12, 102-108.

[67] Yermack, D., 1995, Do corporations award CEO stock options effectively? Journal of Financial Economics 39, 237-269. 


\section{Appendix A - \\ Construction of Longholder_Thomson from Thomson Financial data}

To begin, we download all Table 2 transactions for firms in our Execucomp sample, requiring the role code to equal "CEO." We then filter the results as follows:

1. We keep only observations for which Thomson cleanse codes indicate a reasonable degree of data accuracy ("R," "H," "C," "L," or "I").

2. We drop observations which are amendments of prior records to avoid double-counting transactions (amend = "A").

3. We require the acquisition/disposition flag to indicate that the record represents disposal of securities (acqdisp = "D").

4. We keep only derivative codes which indicate the securities in question are call options ("OPTNS," "ISO," "CALL," "NONQ," "EMPO," "DIRO," "DIREO," "EMPLO," "NON Q," "NONQU," "SAR," "OPTIO," "EMP.", "EMPL").

5. We drop observations with missing strike prices or exercise dates.

6. We drop observations with implausible values of the strike price (xprice $<0.1$ or xprice $>2000$ ).

7. We keep only records with transaction codes indicating option exercises (trancode $=$ "M," "X," "H," or "F")

After applying these filters, we merge the resulting data with monthly stock price data from CRSP. We identify all option exercises which meet two "Longholder" criteria: (1) the exercise occurs within 365 calendar days of option expiration and (2) the option was at least $40 \%$ in the money 12 months prior to the month of expiration (using the CRSP end-of-the-month stock price). We then merge the Thomson data to our Execucomp sample, retaining an option exercise observation only if the insider name in the Thomson data matches the CEO name in Execucomp. Finally, we set the variable Longholder_Thomson or Longholder_Thomson_fill equal to 1 if we observe at least one option exercise meeting the two Longholder criteria during the CEO's tenure in our Execucomp panel. The two Longholder measures differ only in the control groups (i.e. the CEO-years for which the variable is set to 0). For Longholder_Thomson, we include a $\mathrm{CEO}$ in the control group only if we observe at least one option exercise by the CEO in the Thomson data, but never an exercise that meets the two Longholder criteria. For Longholder_Thomson_fill, we include all Execucomp CEOs for whom we never observe an option exercise meeting the two Longholder criteria. 


\section{Figure 1. Model Predictions (Stylized Example)}

The hypothetical example illustrates how overconfident CEOs may deviate from the rational benchmark in their average financing of investment projects holding constant investment opportunities and financing needs. Relative to the (hypothetical) rational benchmark of $1 / 3$ cash, $1 / 3$ debt, and $1 / 3$ equity financing, overconfident CEOs choose a lower absolute amount of debt financing $(2 / 9<1 / 3)$, but a higher leverage $(2 / 3>1 / 2)$ due to even lower absolute amounts of equity financing $(1 / 9<1 / 3)$.

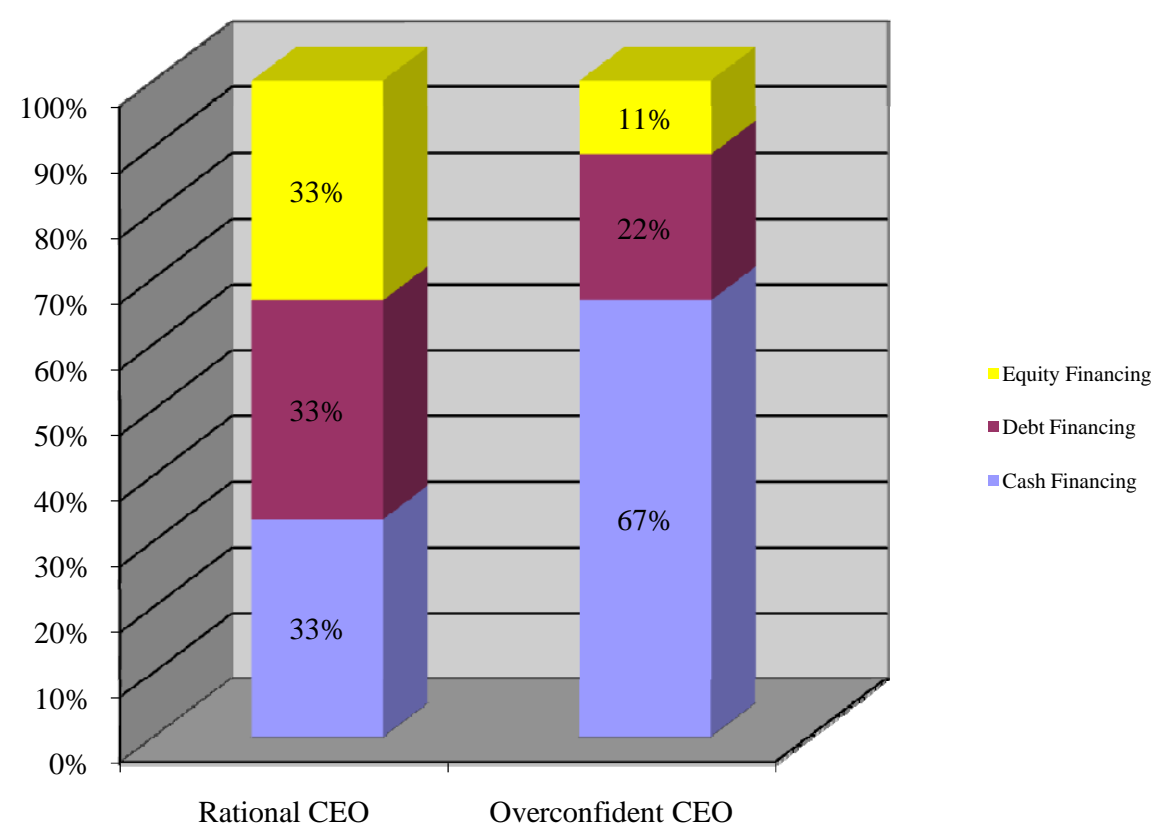


Table I. Empirical Predictions

\begin{tabular}{|c|c|c|c|c|}
\hline & $\begin{array}{c}\text { Preference for } \\
\text { Public Debt vs. } \\
\text { Equity Issues }\end{array}$ & $\begin{array}{l}\text { Preference for Debt } \\
\text { vs. Equity to Fill } \\
\text { External Financing } \\
\text { Needs ("Financing } \\
\text { Deficit") }\end{array}$ & $\begin{array}{l}\text { Debt Level Relative } \\
\text { to Maximum } \\
\text { Available Tax Benefit } \\
\text { ("Kink") }\end{array}$ & Market Leverage \\
\hline Overconfidence & Debt & Debt & Low $^{*}$ & High $^{* * *}$ \\
\hline Depression Baby & no prediction & no prediction & Low & no prediction \\
\hline Military Service & no prediction & no prediction & no prediction & High \\
\hline
\end{tabular}

* For a range of parameter values; see model.

** Cumulative effect. 


\section{Table II. Summary Statistics}

\section{Panel A. Financing Deficit Variables}

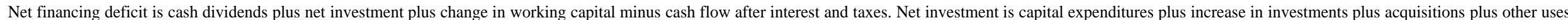

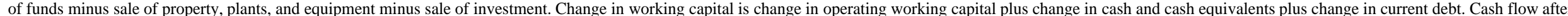

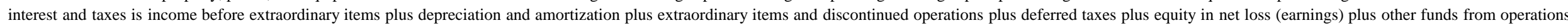

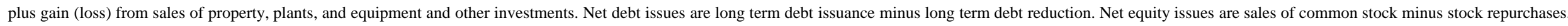

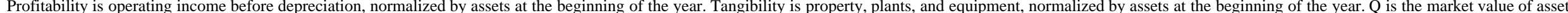

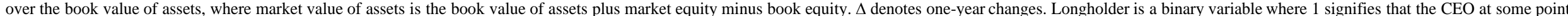
during his tenure held an option package until the last year before expiration, provided that the package was at least $40 \%$ in the money entering its last year.

\begin{tabular}{|c|c|c|c|c|c|c|c|c|c|c|c|c|}
\hline \multirow[b]{3}{*}{ Variable } & \multicolumn{6}{|c|}{$\begin{array}{l}\text { Full Sample } \\
\end{array}$} & \multicolumn{6}{|c|}{ Longholder Sample } \\
\hline & \multicolumn{6}{|c|}{ Number of Firms $=263$} & \multicolumn{6}{|c|}{ Number of Firms $=56$} \\
\hline & Obs. & Mean & Median & SD & Min. & Max. & Obs. & Mean & Median & $\mathrm{SD}$ & Min. & Max. \\
\hline Assets (\$m) & 2385 & 5476.92 & 2111.96 & 13389.44 & 39.64 & 198598.70 & 463 & 4820.30 & 2111.78 & 8763.07 & 48.79 & 79262.00 \\
\hline Net Financing Deficit (\$m) & 2385 & 42.67 & 0.75 & 538.56 & -6800.30 & 8845.50 & 463 & 10.41 & -1.05 & 287.07 & -845.00 & 1698.00 \\
\hline Cash Dividends (\$m) & 2385 & 109.47 & 35.58 & 239.77 & 0.00 & 2487.00 & 463 & 126.59 & 40.69 & 252.09 & 0.00 & 1870.00 \\
\hline Net Investment (\$m) & 2385 & 502.28 & 172.70 & 1311.81 & -2930.00 & 26523.00 & 463 & 498.57 & 207.37 & 1070.84 & -577.00 & 9755.00 \\
\hline Change in Working Capital (\$m) & 2385 & 26.73 & 16.02 & 790.77 & -21767.00 & 16224.00 & 463 & 35.54 & 17.95 & 347.04 & -2920.50 & 2675.00 \\
\hline Cash Flow after Interest and Taxes (\$m) & 2385 & 595.80 & 228.56 & 1276.57 & -1678.44 & 20278.00 & 463 & 650.29 & 254.62 & 1243.20 & -1678.44 & 11273.00 \\
\hline Net Financing Deficit/Assets ${ }_{\mathrm{t}-1}$ & 2385 & 0.03 & 0.00 & 0.16 & -0.63 & 2.56 & 463 & 0.02 & 0.00 & 0.14 & -0.24 & 1.60 \\
\hline Net Debt Issues/Assets t-1 $_{1}$ & 2385 & 0.01 & 0.00 & 0.08 & -0.62 & 0.92 & 463 & 0.01 & 0.00 & 0.06 & -0.15 & 0.36 \\
\hline Net Equity Issues/Assets t-1 & 2155 & 0.00 & 0.00 & 0.08 & -0.77 & 1.85 & 413 & 0.01 & 0.00 & 0.09 & -0.30 & 1.18 \\
\hline Profitability & 2385 & 0.18 & 0.17 & 0.11 & -0.24 & 0.99 & 463 & 0.21 & 0.19 & 0.12 & -0.03 & 0.88 \\
\hline$\Delta$ Profitability & 2385 & 0.00 & 0.00 & 0.06 & -0.76 & 0.98 & 463 & 0.00 & 0.00 & 0.08 & -0.51 & 0.98 \\
\hline Tangibility & 2385 & 0.44 & 0.42 & 0.22 & 0.00 & 2.08 & 463 & 0.46 & 0.43 & 0.21 & 0.06 & 2.08 \\
\hline$\Delta$ Tangibility & 2385 & -0.05 & -0.03 & 0.11 & -1.47 & 0.54 & 463 & -0.05 & -0.03 & 0.12 & -1.47 & 0.16 \\
\hline $\mathrm{Q}$ & 2385 & 1.61 & 1.30 & 1.01 & 0.59 & 12.26 & 463 & 1.70 & 1.44 & 1.02 & 0.77 & 10.71 \\
\hline$\Delta \mathrm{Q}$ & 2385 & 0.01 & 0.01 & 0.50 & -7.18 & 5.04 & 463 & 0.03 & 0.02 & 0.42 & -1.81 & 4.32 \\
\hline $\ln$ (Sales) & 2385 & 7.90 & 7.82 & 1.12 & 3.18 & 11.93 & 463 & 7.89 & 7.87 & 1.18 & 3.18 & 11.23 \\
\hline$\Delta \ln ($ Sales $)$ & 2385 & 0.08 & 0.07 & 0.19 & -2.04 & 1.67 & 463 & 0.09 & 0.08 & 0.17 & -0.55 & 1.67 \\
\hline
\end{tabular}

\section{Distribution across Fama French 12 Industry Groups}

\begin{tabular}{|c|c|c|c|c|c|c|c|}
\hline \multicolumn{4}{|c|}{ (2381 observations) } & \multicolumn{4}{|c|}{ (463 observations) } \\
\hline Consumer Nondurables & 0.13 & Telecommunication & 0.06 & Consumer ND & 0.11 & Telecommunication & 0.02 \\
\hline Consumer Durables & 0.05 & Utilities & $\mathrm{n} / \mathrm{a}$ & Consumer Durables & 0.03 & Utilities & $\mathrm{n} / \mathrm{a}$ \\
\hline Manufacturing & 0.18 & Shops & 0.14 & Manufacturing & 0.16 & Shops & 0.14 \\
\hline Energy & 0.04 & Health & 0.06 & Energy & 0.00 & Health & 0.09 \\
\hline Chemicals and Allied Products & 0.08 & Money & $\mathrm{n} / \mathrm{a}$ & Chemicals & 0.16 & Money & $\mathrm{n} / \mathrm{a}$ \\
\hline Business Equipment & 0.09 & Other & 0.18 & Business Equipment & 0.13 & Other & 0.17 \\
\hline
\end{tabular}

The Fama-French Industry Groups are defined on French's website (http://mba.tuck.dartmouth.edu/pages/faculty/ken.french/data_library.html). 


\section{Table II (cont.)}

Panel B. Kink Variables

Kink is the amount of interest at the point where the marginal benefit function becomes downward sloping, as a proportion of actual interest expense. ECOST is the standard deviation of the first difference in taxable earnings divided by assets, the quoteient times the sum of advertising, research, and development expenses divided by sales. CYCLICAL is the standard deviation of operating earnings divided by mean assets first calculated for each firm, then averaged across firms within two-digit SIC codes. Return on assets is income before extraordinary items plus interest expense plus depreciation, divided by assets. Z-score is 3.3 times the difference of operating income before depreciation and depreciation plus sales plus 1.4 times retained earnings plus 1.2 times working capital (balance sheet), the quantity divided by assets. Quick ratio is the sum of cash and short-term investments and total receivables divided by total current liabilities. Current ratio is total current assets divided by total current liabilities. Q-ratio is preferred stock plus market value of common equity plus net short-term liabilities, the quantity divided by assets. R\&D to sales and Advertising to sales are set to 0 when the numerator is missing. Computer Industry are all firms with SIC code 357, Semiconductor Industry all firms with SIC code 367, Chemicals and Allied Products comprises SIC codes 280-289, Aircraft and Guided Space Vehicles SIC codes 372 and 376, and Other Sensitive Industries SIC codes 340-400, excluding 357, 367, 372, and 376. Longholder is a binary variable where 1 signifies that the $\mathrm{CEO}$ at some point during his tenure held an option package until the last year before expiration, provided that the package was at least $40 \%$ in the money entering its last year.

\begin{tabular}{|c|c|c|c|c|c|c|c|c|c|c|c|c|}
\hline \multirow[b]{3}{*}{ Variable } & \multicolumn{6}{|c|}{ Full Sample } & \multicolumn{6}{|c|}{ Longholder Sample } \\
\hline & \multicolumn{6}{|c|}{ Number of Firms $=189$} & \multicolumn{6}{|c|}{ Number of Firms $=44$} \\
\hline & Obs. & Mean & Median & SD & Min. & Max. & Obs. & Mean & Median & SD & Min. & Max. \\
\hline Kink & 1726 & 3.93 & 3 & 2.74 & 0 & 8 & 377 & 4.59 & 4 & 2.75 & 0 & 8 \\
\hline I(No dividend) & 1726 & 0.12 & 0 & 0.33 & 0 & 1 & 377 & 0.17 & 0 & 0.38 & 0 & 1 \\
\hline I(Negative owners' equity) & 1726 & 0.01 & 0 & 0.12 & 0 & 1 & 377 & 0 & 0 & 0 & 0 & 0 \\
\hline I(NOL carryforward) & 1726 & 0.15 & 0 & 0.36 & 0 & 1 & 377 & 0.14 & 0 & 0.35 & 0 & 1 \\
\hline ECOST & 1726 & 1.74 & 0.65 & 3.21 & 0 & 18.92 & 377 & 2.36 & 0.79 & 3.92 & 0 & 18.92 \\
\hline CYCLICAL & 1726 & 0.07 & 0.07 & 0.03 & 0.02 & 0.18 & 377 & 0.08 & 0.07 & 0.02 & 0.04 & 0.18 \\
\hline Return on assets & 1726 & 0.13 & 0.14 & 0.05 & -0.06 & 0.27 & 377 & 0.14 & 0.14 & 0.05 & -0.06 & 0.27 \\
\hline $\ln$ (sales) & 1726 & 7.88 & 7.82 & 1.01 & 5.49 & 10.32 & 377 & 7.93 & 7.87 & 1.07 & 5.49 & 10.32 \\
\hline Z-score & 1726 & 2.51 & 2.34 & 1.17 & 0.38 & 7.07 & 377 & 2.74 & 2.51 & 1.24 & 0.79 & 7.07 \\
\hline Quick ratio & 1726 & 1.08 & 0.89 & 0.74 & 0.16 & 4.92 & 377 & 1.12 & 0.94 & 0.71 & 0.16 & 4.92 \\
\hline Current ratio & 1726 & 1.88 & 1.63 & 0.96 & 0.57 & 6.02 & 377 & 1.97 & 1.71 & 0.94 & 0.58 & 6.02 \\
\hline PPE-to-assets & 1726 & 0.42 & 0.40 & 0.18 & 0.06 & 0.81 & 377 & 0.41 & 0.39 & 0.16 & 0.06 & 0.81 \\
\hline Q-ratio & 1726 & 1.12 & 0.88 & 0.78 & 0.15 & 4.58 & 377 & 1.22 & 0.99 & 0.83 & 0.15 & 4.58 \\
\hline R\&D-to-sales & 1726 & 0.02 & 0.01 & 0.03 & 0 & 0.16 & 377 & 0.03 & 0.02 & 0.04 & 0 & 0.16 \\
\hline Advertising-to-sales & 1726 & 0.02 & 0 & 0.03 & 0 & 0.16 & 377 & 0.02 & 0.01 & 0.03 & 0 & 0.16 \\
\hline Computer Industry & 1726 & 0.04 & 0 & 0.19 & 0 & 1 & 377 & 0.07 & 0 & 0.25 & 0 & 1 \\
\hline Semiconductor Industry & 1726 & 0.02 & 0 & 0.14 & 0 & 1 & 377 & 0.03 & 0 & 0.16 & 0 & 1 \\
\hline Chemicals and Allied Products Industry & 1726 & 0.14 & 0 & 0.35 & 0 & 1 & 377 & 0.21 & 0 & 0.41 & 0 & 1 \\
\hline Aircraft and Guided Space Vehicles Industry & 1726 & 0.02 & 0 & 0.13 & 0 & 1 & 377 & 0.02 & 0 & 0.14 & 0 & 1 \\
\hline Other Sensitive Industries & 1726 & 0.19 & 0 & 0.39 & 0 & 1 & 377 & 0.15 & 0 & 0.35 & 0 & 1 \\
\hline
\end{tabular}

\section{Panel C. CEO Variables}

CEO Vested Options are the CEO's holdings of options that are exercisable within 6 months of the beginning of the year (as a \% of shares outstanding), multiplied by 10 so that the means of vested options and CEO Stock Ownership are the same order of magnitude. Depression Baby is an indicator variable for CEOs born in the 1920s. Military Experience indicates CEOs with prior military service.

\begin{tabular}{|c|c|c|c|c|c|c|c|c|c|c|c|c|}
\hline \multirow[b]{3}{*}{ Variable } & \multicolumn{6}{|c|}{ Full Sample } & \multicolumn{6}{|c|}{ Longholder Sample } \\
\hline & \multicolumn{6}{|c|}{ Number of CEOs $=498$} & \multicolumn{6}{|c|}{ Number of CEOs $=58$} \\
\hline & Obs. & Mean & Median & SD & Min. & Max. & Obs. & Mean & Median & SD & Min. & Max. \\
\hline$\overline{\text { Age }}$ & 2384 & 57.77 & 58 & 7.16 & 32 & 84 & 463 & 58.46 & 59 & 6.30 & 41 & 82 \\
\hline Tenure & 2364 & 8.83 & 6 & 7.69 & 1 & 45 & 442 & 10.78 & 9 & 6.78 & 1 & 36 \\
\hline CEO Stock Ownership & 2385 & 0.03 & 0.00 & 0.08 & 0 & 0.95 & 463 & 0.02 & 0.00 & 0.04 & 0 & 0.49 \\
\hline CEO Vested Options & 2385 & 0.03 & 0.01 & 0.14 & 0 & 4.63 & 463 & 0.07 & 0.02 & 0.29 & 0 & 4.63 \\
\hline Depression Baby & 2384 & 0.40 & 0 & 0.49 & 0 & 1 & 463 & 0.49 & 0 & 0.50 & 0 & 1 \\
\hline Military Experience & 1617 & 0.22 & 0 & 0.41 & 0 & 1 & 352 & 0.28 & 0 & 0.45 & 0 & 1 \\
\hline
\end{tabular}




\section{Table III. Correlations of Depression Baby and Military Experience with Firm and CEO Characteristics}

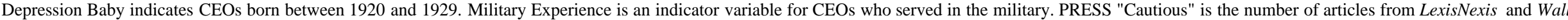

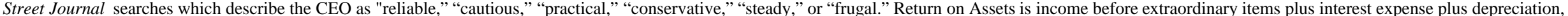

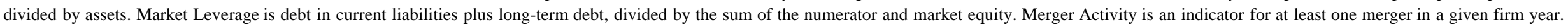

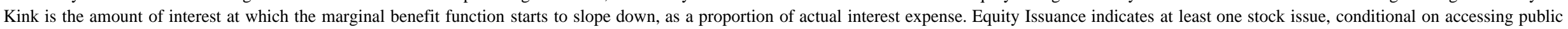
securities markets.

\begin{tabular}{|c|c|c|c|c|c|c|c|c|c|c|c|}
\hline & $\begin{array}{c}\text { Depression } \\
\text { Baby }\end{array}$ & $\begin{array}{c}\text { Military } \\
\text { Experience }\end{array}$ & $\begin{array}{c}\text { PRESS } \\
\text { "Cautious" }\end{array}$ & Age & Tenure & $\begin{array}{l}\text { Return on } \\
\text { Assets }\end{array}$ & $\begin{array}{l}\text { CEO Stock } \\
\text { Ownership }\end{array}$ & Leverage & $\begin{array}{l}\text { Merger } \\
\text { Activity }\end{array}$ & Kink & $\begin{array}{l}\text { Equity } \\
\text { Issuance }\end{array}$ \\
\hline Depression Baby & $\begin{array}{c}1 \\
(-; 3617)\end{array}$ & & & & & & & & & & \\
\hline Military Experience & $\begin{array}{c}0.1472 \\
(0.00 ; 2320)\end{array}$ & $\begin{array}{c}1 \\
(-; 3617)\end{array}$ & & & & & & & & & \\
\hline PRESS "Cautious" & $\begin{array}{c}0.036 \\
(0.03 ; 3580)\end{array}$ & $\begin{array}{c}-0.08 \\
(0.00 ; 2378)\end{array}$ & $\begin{array}{c}1 \\
(-; 3803)\end{array}$ & & & & & & & & \\
\hline Age & $\begin{array}{c}0.3766 \\
(0.00 ; 3617)\end{array}$ & $\begin{array}{c}0.1332 \\
(0.00 ; 2320)\end{array}$ & $\begin{array}{c}0.0194 \\
(0.25 ; 3580)\end{array}$ & $\begin{array}{c}1 \\
(-; 3617)\end{array}$ & & & & & & & \\
\hline Tenure & $\begin{array}{c}0.1009 \\
(0.00 ; 3500)\end{array}$ & $\begin{array}{c}-0.056 \\
(0.01 ; 2250)\end{array}$ & $\begin{array}{c}0.154 \\
(0.00 ; 3471)\end{array}$ & $\begin{array}{c}0.3668 \\
(0.00 ; 3500)\end{array}$ & $\begin{array}{c}1 \\
(-; 3501)\end{array}$ & & & & & & \\
\hline Return on Assets & $\begin{array}{c}0.0680 \\
(0.00 ; 3454)\end{array}$ & $\begin{array}{c}-0.0808 \\
(0.00 ; 2267)\end{array}$ & $\begin{array}{c}-0.0162 \\
(0.33 ; 3560)\end{array}$ & $\begin{array}{c}0.0012 \\
(0.95 ; 3454)\end{array}$ & $\begin{array}{c}0.0289 \\
(0.09 ; 3362)\end{array}$ & $\begin{array}{c}1 \\
(-; 4393)\end{array}$ & & & & & \\
\hline CEO Stock Ownership & $\begin{array}{c}-0.1061 \\
(0.00 ; 3496)\end{array}$ & $\begin{array}{c}-0.0941 \\
(0.00 ; 2258)\end{array}$ & $\begin{array}{c}0.1003 \\
(0.00 ; 3465)\end{array}$ & $\begin{array}{c}-0.0332 \\
(0.05 ; 3496)\end{array}$ & $\begin{array}{c}0.3084 \\
(0.00 ; 3454)\end{array}$ & $\begin{array}{c}0.0164 \\
(0.34 ; 3360)\end{array}$ & $\begin{array}{c}1 \\
(-; 3497)\end{array}$ & & & & \\
\hline Market Leverage & $\begin{array}{c}-0.0586 \\
(0.00 ; 3504)\end{array}$ & $\begin{array}{c}0.0227 \\
(0.28 ; 2263)\end{array}$ & $\begin{array}{c}-0.0272 \\
(0.10 ; 3558)\end{array}$ & $\begin{array}{c}-0.0337 \\
(0.05 ; 3504)\end{array}$ & $\begin{array}{c}-0.0911 \\
(0.00 ; 3425)\end{array}$ & $\begin{array}{c}-0.3792 \\
(0.00 ; 4281)\end{array}$ & $\begin{array}{c}-0.0579 \\
(0.00 ; 3425)\end{array}$ & $\begin{array}{c}1 \\
(-; 4528)\end{array}$ & & & \\
\hline Merger Acitivity & $\begin{array}{c}0.0085 \\
(0.61 ; 3617)\end{array}$ & $\begin{array}{c}0.0674 \\
(0.00 ; 2378)\end{array}$ & $\begin{array}{c}-0.0199 \\
(0.22 ; 3803)\end{array}$ & $\begin{array}{c}-0.0278 \\
(0.09 ; 3617)\end{array}$ & $\begin{array}{c}-0.0300 \\
(0.08 ; 3501)\end{array}$ & $\begin{array}{c}-0.0513 \\
(0.00 ; 4393)\end{array}$ & $\begin{array}{c}-0.0105 \\
(0.53: 3497)\end{array}$ & $\begin{array}{c}0.0045 \\
(0.76 ; 4528)\end{array}$ & $\begin{array}{c}1 \\
(-; 5131)\end{array}$ & & \\
\hline Kink & $\begin{array}{c}0.1129 \\
(0.00 ; 2846)\end{array}$ & $\begin{array}{c}-0.022 \\
(0.34 ; 1868)\end{array}$ & $\begin{array}{c}-0.0347 \\
(0.06 ; 2917)\end{array}$ & $\begin{array}{c}0.0305 \\
(0.10: 2846)\end{array}$ & $\begin{array}{c}0.0598 \\
(0.00 ; 2764)\end{array}$ & $\begin{array}{c}0.4318 \\
(0.00 ; 2912)\end{array}$ & $\begin{array}{c}0.0977 \\
(0.00 ; 2770)\end{array}$ & $\begin{array}{c}-0.6468 \\
(0.00 ; 2900)\end{array}$ & $\begin{array}{c}-0.0300 \\
(0.10 ; 2978)\end{array}$ & $\begin{array}{c}1 \\
(-; 2978)\end{array}$ & \\
\hline Equity Issuance & $\begin{array}{c}-0.0829 \\
(0.02 ; 739)\end{array}$ & $\begin{array}{c}0.1105 \\
(0.01 ; 524) \\
\end{array}$ & $\begin{array}{c}-0.0098 \\
(0.79 ; 756) \\
\end{array}$ & $\begin{array}{c}-0.1534 \\
(0.00 ; 739) \\
\end{array}$ & $\begin{array}{c}-0.0314 \\
(0.40 ; 727) \\
\end{array}$ & $\begin{array}{c}-0.0477 \\
(0.19 ; 748) \\
\end{array}$ & $\begin{array}{c}0.0458 \\
(0.22 ; 718) \\
\end{array}$ & $\begin{array}{c}-0.0955 \\
(0.01 ; 752) \\
\end{array}$ & $\begin{array}{c}0.0392 \\
(0.28 ; 769) \\
\end{array}$ & $\begin{array}{c}-0.0953 \\
(0.01 ; 654) \\
\end{array}$ & $\begin{array}{c}1 \\
(-; 769) \\
\end{array}$ \\
\hline
\end{tabular}

p-values and number of observations in parentheses 


\section{Table IV. Debt vs. Equity (I): Public Issues}

\section{Panel A. Frequencies}

Longholder is a binary variable, equal to 1 if the CEO, at some point during his tenure, held an option package until the last year before expiration, provided that the package was at least $40 \%$ in the money entering its last year. Post-Longholder is equal to 1 for all CEO-years after the CEO for the first time holds options to expiration. Pre-Longholder is Longholder minus Post-Longholder. Holder 67 is a binary variable, equal to 1 for all CEO years after the CEO for the first time fails to exercise a $67 \%$ in-the-money option with 5 years remaining duration. For Holder 67, the sample is limited to CEO-years after the CEO for the first time had a $67 \%$ in-the-money option with 5 years remaining duration. TOTALconfident is binary and equal to 1 when the number of "confident" and "optimistic" mentions for a CEO in the LexisNexis and Wall Street Journal searches exceeds the number of "not confident," "not optimistic," and "reliable, cautious, practical, conservative, steady, frugal" mentions. TOTALmentions is the total number of articles mentioning the CEO in those searches. Both TOTAL-variables include all articles over the sample period up to the previous year. Data on public issues is from SDC. There are 330 firms. Equity issues are issues of common stock or non-convertible preferred stock. Debt issues are issues of non-convertible debt. Hybrid issues are issues of convertible debt or convertible preferred stock. US Rule 144A issues are included. Standard errors are adjusted for clustering at the firm level.

\begin{tabular}{|c|c|c|c|c|}
\hline & \multirow[b]{2}{*}{$\begin{array}{l}\text { Number of Years with Any } \\
\text { Security Issues }\end{array}$} & \multicolumn{3}{|c|}{ \% of Issue Years with } \\
\hline & & Equity Issues & Debt Issues & Hybrid Issues \\
\hline Longholder $=0$ & 621 & $42 \%$ & $57 \%$ & $16 \%$ \\
\hline Longholder $=1$ & 141 & $31 \%$ & $63 \%$ & $19 \%$ \\
\hline Pre-Longholder $=1$ & 91 & $31 \%$ & $63 \%$ & $23 \%$ \\
\hline Post-Longholder $=1$ & 50 & $32 \%$ & $64 \%$ & $12 \%$ \\
\hline Difference $t$ (Longholder $=0$ - Longholder $=1$ ) & & $2.03 * *$ & 0.85 & 0.85 \\
\hline Holder $67=0$ & 95 & $39 \%$ & $65 \%$ & $21 \%$ \\
\hline Holder $67=1$ & 182 & $23 \%$ & $73 \%$ & $16 \%$ \\
\hline Difference $t$ & & $3.12 * * *$ & 1.18 & 1.04 \\
\hline TOTALconfident $=0$ & 452 & $48 \%$ & $47 \%$ & $18 \%$ \\
\hline TOTALconfident $=1$ & 214 & $25 \%$ & $79 \%$ & $14 \%$ \\
\hline Difference $t$ & & $5.37 * * *$ & $6.77^{* * *}$ & 1.43 \\
\hline
\end{tabular}

* significant at $10 \%$; ** significant at $5 \%$; *** significant at $1 \%$

\section{Panel B. Logit Regressions}

Coefficients are reported as log odds ratios. The sample consists of all firm years in which the firm did at least one public security issue. The dependent variable is binary and equals 1 if the firm issued equity during the fiscal year. CEO Vested Options are the CEO's holdings of options that are exercisable within 6 months of the beginning of the year (as a \% of shares outstanding), multiplied by 10 so that the means of vested options and CEO Stock Ownership are the same order of magnitude. The Standard firm controls are $\ln ($ Sales), Q (market value of assets over the book value of assets, where market value of assets is the book value of total assets plus market equity minus book equity), Profitability (operating income before depreciation normalized by beginning-ofyear assets), Tangibility (property, plants, and equipment, normalized by beginning-of-year assets). Book leverage is the sum of debt in current liabilities and long term debt, divided by the sum of the numerator and common equity. We exclude observations in which book leverage is negative or greater than 1 . CEO Stock, CEO Vested Options, ln(Sales), Q, Profitability, Tangibility, and Book Leverage are measured at the beginning of the fiscal year. Kink controls are defined as in Graham (2002) and listed in Table 1, Panel B. Industry Fixed Effects are the kink-regression industry dummies of Graham (2000). Standard errors are adjusted for clustering at the firm level.

\begin{tabular}{|c|c|c|c|c|c|c|}
\hline & $(1)$ & (2) & (3) & $(4)$ & $(5)$ & $(6)$ \\
\hline \multirow[t]{2}{*}{ Longholder } & -0.469 & -0.592 & -0.534 & -0.46 & -0.457 & -0.6695 \\
\hline & $(1.94)^{*}$ & $(2.34)^{* *}$ & $(2.10)^{* *}$ & $(1.80)^{*}$ & $(1.66)^{*}$ & $(2.22)^{* *}$ \\
\hline \multirow[t]{2}{*}{ CEO Stock Ownership } & & -0.266 & -0.996 & -1.279 & -0.655 & -7.6403 \\
\hline & & $(0.16)$ & $(0.59)$ & $(0.72)$ & $(0.34)$ & $(2.35)^{* *}$ \\
\hline \multirow[t]{2}{*}{ CEO Vested Options } & & 6.766 & 4.669 & 4.234 & 7.328 & 10.6238 \\
\hline & & $(3.43)^{* * *}$ & $(2.21)^{* *}$ & $(2.14)^{* *}$ & $(3.05)^{* * *}$ & $(2.81)^{* * *}$ \\
\hline Standard firm controls & & & $\mathrm{X}$ & $\mathrm{X}$ & $\mathrm{X}$ & \\
\hline Book leverage & & & & $\mathrm{X}$ & $\mathrm{X}$ & \\
\hline Kink controls & & & & & & $\mathrm{X}$ \\
\hline Industry fixed effects & & & & & & $\mathrm{X}$ \\
\hline Year fixed effects & & & & & $\mathrm{X}$ & $\mathrm{X}$ \\
\hline Observations & 762 & 644 & 627 & 617 & 617 & 442 \\
\hline Number of Firms & 330 & 174 & 171 & 171 & 171 & 135 \\
\hline
\end{tabular}

* significant at $10 \%$; ** significant at $5 \%$; *** significant at $1 \%$ 


\section{Table V. Debt vs. Equity (II): Financing Deficit}

OLS regressions with Net Debt Issues normalized by beginning-of-the-year assets as the dependent variable, where Net Debt Issues are long-term debt issues minus long term debt reduction. Net Financing Deficit is cash dividends plus net investment plus change in working capital minus cash flow after interest and taxes, normalized by beginning-of-the-year assets. Net investment is capital expenditures plus increase in investments plus acquisitions plus other uses of funds minus sale of PPE minus sale of investment. Change in working capital is change in operating working capital plus change in cash and cash equivalents plus change in current debt. Cash flow after interest and taxes is income before extraordinary items plus depreciation and amortization plus extraordinary items and discontinued operations plus deferred taxes plus equity in net loss (earnings) plus other funds from operations plus gain (loss) from sales of PPE and other investments. Longholder is a binary variable where 1 signifies that the $\mathrm{CEO}$ at some point during his tenure held an option package until the last year before expiration, provided that the package was at least $40 \%$ in the money entering its last year. CEO Vested Options are the CEO's holdings of options that are exercisable within 6 months of the beginning of the year (as a \% of shares outstanding), multiplied by 10 so that the means of vested options and CEO Stock Ownership are the same order of magnitude. The FD Control Variables are identical to those in Frank and Goyal (2003): changes in profitability (operating income before depreciation normalized by beginning of the year assets), in tangibility (property, plants, and equipment, normalized by beginning of the year assets), in the logarithm of sales and in Q (market value of assets over the book value of assets, where market value of assets is the book value of total assets plus market equity minus book equity). Book Leverage is debt in current liabilities plus long-term debt divided by the debt in current liabilities plus long-term debt plus common equity, measured at the beginning of the year. All standard errors are adjusted for clustering at the firm level.

\begin{tabular}{|c|c|c|c|c|c|c|}
\hline & $(1)$ & $(2)$ & (3) & $(4)$ & $(5)$ & $(6)$ \\
\hline Net Financing Deficit (FD) & $\begin{array}{c}0.729 \\
(9.90)^{* * *}\end{array}$ & & & & & \\
\hline Longholder & & $\begin{array}{l}-0.006 \\
(1.43)\end{array}$ & $\begin{array}{l}-0.005 \\
(1.37)\end{array}$ & $\begin{array}{l}-0.008 \\
(1.95)^{*}\end{array}$ & $\begin{array}{l}-0.008 \\
(2.03)^{* *}\end{array}$ & $\begin{array}{l}-0.005 \\
(1.43)\end{array}$ \\
\hline Longholder * FD & & $\begin{array}{c}0.350 \\
(1.78)^{*}\end{array}$ & $\begin{array}{c}0.348 \\
(1.77)^{*}\end{array}$ & $\begin{array}{c}0.332 \\
(1.77)^{*}\end{array}$ & $\begin{array}{c}0.322 \\
(1.69)^{*}\end{array}$ & $\begin{array}{c}0.334 \\
(1.90)^{*}\end{array}$ \\
\hline CEO Stock Ownership & & & $\begin{array}{l}0.015 \\
(0.87)\end{array}$ & $\begin{array}{l}0.015 \\
(0.90)\end{array}$ & $\begin{array}{l}0.014 \\
(0.85)\end{array}$ & $\begin{array}{l}0.010 \\
(0.76)\end{array}$ \\
\hline CEO Stock * FD & & & $\begin{array}{c}0.373 \\
(2.30)^{* *}\end{array}$ & $\begin{array}{c}0.431 \\
(2.63)^{* * *}\end{array}$ & $\begin{array}{c}0.370 \\
(2.14)^{* *}\end{array}$ & $\begin{array}{c}0.348 \\
(2.17)^{* *}\end{array}$ \\
\hline CEO Vested Options & & & $\begin{array}{l}-0.025 \\
(1.49)\end{array}$ & $\begin{array}{l}-0.021 \\
(1.15)\end{array}$ & $\begin{array}{l}0.000 \\
(0.00)\end{array}$ & $\begin{array}{l}0.011 \\
(0.52)\end{array}$ \\
\hline CEO Vested Options * FD & & & $\begin{array}{c}-0.088 \\
(3.21)^{* * *}\end{array}$ & $\begin{array}{c}-0.098 \\
(3.59)^{* * *}\end{array}$ & $\begin{array}{c}-0.135 \\
(3.06)^{* * *}\end{array}$ & $\begin{array}{c}-0.156 \\
(3.76)^{* * *}\end{array}$ \\
\hline Book Leverage & & & & & & $\begin{array}{c}-0.096 \\
(5.98)^{* * *}\end{array}$ \\
\hline Book Leverage * FD & & & & & & $\begin{array}{l}-0.129 \\
(0.54)\end{array}$ \\
\hline $\begin{array}{l}\text { FD Control Variables } \\
\text { FD Control Variables * FD }\end{array}$ & & & & & $\begin{array}{l}X \\
X\end{array}$ & $\begin{array}{l}X \\
X\end{array}$ \\
\hline Year Fixed Effects & & & & $\mathrm{X}$ & $\mathrm{X}$ & $\mathrm{X}$ \\
\hline Firm Fixed Effects & & $\mathrm{X}$ & $\mathrm{X}$ & $\mathrm{X}$ & $\mathrm{X}$ & $\mathrm{X}$ \\
\hline Firm Fixed Effects * FD & & $\mathrm{X}$ & $\mathrm{X}$ & $\mathrm{X}$ & $\mathrm{X}$ & $\mathrm{X}$ \\
\hline Observations & 2385 & 2385 & 2385 & 2385 & 2385 & 2346 \\
\hline Number of Firms & 263 & 263 & 263 & 263 & 263 & 262 \\
\hline R-squared & 0.75 & 0.93 & 0.93 & 0.94 & 0.94 & 0.94 \\
\hline
\end{tabular}

* significant at $10 \%$; ** significant at $5 \%$; *** significant at $1 \%$ 


\section{Table VI. Internal vs. External Financing}

\section{Panel A. Debt Conservatism: Kink Tobits}

The dependent variable is the kink variable of Graham (2000), i. e., the amount of hypothetical interest at which the marginal tax benefit function starts to slope down, as a proportion of actual interest expense. The tobit regressions account for two-sided censoring of the kink variable at 0 and 8 . Longholder is a binary variable, equal to 1 if the CEO, at some point during his tenure, held an option package until the last year before expiration, provided that the package was at least $40 \%$ in the money entering its last year. Depression Baby indicates CEOs born between 1920 and 1929 . CEO Stock Ownership is the percentage of company stock owned by the CEO and his immediate family at the beginning of the year. CEO Vested Options are the CEO's holdings of options that are exercisable within 6 months of the beginning of the year (as a \% of shares outstanding), multiplied by 10 so that the means of vested options and CEO Stock Ownership are the same order of magnitude. Kink Controls and Industry Fixed Effects are defined as in Graham (2002) and listed in Panel B of Table 1. Low Cash Status is an indicator, equal to 1 if the firm's cash stock at the beginning of the year, divided by mean industry investment, is at or below the 40th percentile in our sample. Mean industry investment is calculated separately for each year and each of 12 Fama-French industry groups. (See Table 1, Panel A.) All standard errors are adjusted for clustering at the firm level.

\begin{tabular}{|c|c|c|c|c|c|c|}
\hline & (1) & (2) & (3) & (4) & (5) & (6) \\
\hline Longholder & 1.122 & 1.256 & $\begin{array}{l}0.647 \\
(171)^{*}\end{array}$ & & & 0.618 \\
\hline Depression Baby & $(1 . / 5)^{*}$ & & & $\begin{array}{c}0.898 \\
(2.27)^{* *}\end{array}$ & $\begin{array}{c}0.505 \\
(2.07)^{* *}\end{array}$ & $\begin{array}{l}0.484 \\
(1.90)^{*}\end{array}$ \\
\hline CEO Stock Ownership & & $\begin{array}{c}3.369 \\
(1.01)\end{array}$ & $\begin{array}{c}-1.145 \\
(-0.48)\end{array}$ & & & $\begin{array}{c}0.296 \\
(0.11)\end{array}$ \\
\hline CEO Vested Options & & $\begin{array}{c}-3.025 \\
(-0.70)\end{array}$ & $\begin{array}{c}-3.193 \\
(-2.02)^{* *}\end{array}$ & & & $\begin{array}{l}-2.752 \\
(-1.84)^{*}\end{array}$ \\
\hline Age & & & & & $\begin{array}{c}-0.026 \\
(-1.38)\end{array}$ & $\begin{array}{c}-0.022 \\
(-1.15)\end{array}$ \\
\hline Tenure & & & & & $\begin{array}{c}-0.016 \\
(-0.88)\end{array}$ & $\begin{array}{c}-0.023 \\
(-1.22)\end{array}$ \\
\hline Kink Controls & & & $\mathrm{X}$ & & $\mathrm{X}$ & $\mathrm{X}$ \\
\hline Industry Fixed Effects & & & $\mathrm{X}$ & & $\mathrm{X}$ & $\mathrm{X}$ \\
\hline$\overline{\text { Observations }}$ & 1726 & 1726 & 1726 & 1717 & 1717 & 1705 \\
\hline Number of Firms & 189 & 189 & 189 & 190 & 190 & 188 \\
\hline
\end{tabular}

* significant at $10 \%$; ** significant at $5 \%$; *** significant at $1 \%$

Panel B. Equity Conservatism: Distribution of Longholder Net Equity Issues by Kink

Net equity issues are sales of common stock minus stock repurchases and are normalized by beginning of the year assets.

\begin{tabular}{lcccc}
\hline \hline & Kink $\leq 1$ & $1<$ Kink $\leq 3$ & $3<$ Kink $\leq 7$ & Kink $>7$ \\
\hline Sample: Longholder $=1$ & & & & \\
10th percentile & -0.00834 & -0.02923 & -0.02668 & -0.05162 \\
25th percentile & 0.00000 & -0.00003 & -0.01055 & -0.01286 \\
50th percentile & 0.00544 & 0.00180 & 0.00000 & 0.00000 \\
75th percentile & 0.04148 & 0.00629 & 0.00348 & 0.00794 \\
90th percentile & 0.09536 & 0.01733 & 0.02928 & 0.01685 \\
\hline Observations & 37 & 110 & 111 & 96 \\
Mean & 0.02869 & 0.00600 & 0.00497 & 0.00352 \\
Standard Deviation & 0.06086 & 0.05291 & 0.08199 & 0.09174 \\
\hline Sample: Depression Baby 1 & & & & \\
10th percentile & -0.00846 & -0.03568 & -0.04293 & -0.06254 \\
25th percentile & 0.00000 & -0.00855 & -0.01158 & -0.02315 \\
50th percentile & 0.00104 & 0.00047 & 0.00001 & 0.00000 \\
75th percentile & 0.00800 & 0.00570 & 0.00575 & 0.00523 \\
90th percentile & 0.05131 & 0.04080 & 0.01893 & 0.01646 \\
\hline Observations & 74 & 270 & 240 & 175 \\
Mean & 0.00950 & 0.00277 & -0.00088 & -0.01053 \\
Standard Deviation & 0.03470 & 0.05085 & 0.07096 & 0.06885 \\
\hline \hline
\end{tabular}


Table VII. Leverage

OLS regressions with end-of-fiscal-year market leverage as dependent variable, measured as debt in current liabilities plus long-term debt divided by the sum of the numerator and market equity. Longholder is binary and equals 1 if the CEO at some point during his tenure held an option package until the last year before expiration, provided that the package was at least $40 \%$ in the money entering its last year. Military Experience is an indicator variable for CEOs with prior military service; World War II Veteran indicates service during World War II. Profitability is operating income before depreciation normalized by beginning-of-the-year assets; Tangibility is property, plants, and equipment, normalized by beginning-of-the-year assets. Q is the market value of assets over the book value of assets, where market value of assets is the book value of total assets plus market equity minus book equity. Net Financing Deficit is cash dividends plus net investment plus change in working capital minus cash flow after interest and taxes, normalized by beginning-of-the-year assets. Net investment is capital expenditures plus increase in investments plus acquisitions plus other uses of funds minus sale of PPE minus sale of investment. Change in working capital is change in operating working capital plus change in cash and cash equivalents plus change in current debt. Cash flow after interest and taxes is income before extraordinary items plus depreciation and amortization plus extraordinary items and discontinued operations plus deferred taxes plus equity in net loss (earnings) plus other funds from operations plus gain (loss) from sales of PPE and other investments. Returns ${ }_{\mathrm{x}}$ are the natural logarithm of 1 plus stock returns (excluding dividends) from year $\mathrm{x}-1$ to x. CEO Vested Options are the CEO's holdings of options that are exercisable within 6 months of the beginning of the year (as a \% of shares outstanding), multiplied by 10 so that the means of vested options and CEO Stock Ownership are the same order of magnitude. Profitability, Tangibility, ln(Sales), Q, Net Financing Deficit, and CEO Stock Ownership are measured at the beginning of the fiscal year. All standard errors are adjusted for clustering at the firm level.

\begin{tabular}{|c|c|c|c|c|c|c|c|c|c|}
\hline \multirow{2}{*}{ Longholder } & $(1)$ & $(2)$ & (3) & $(4)$ & $(5)$ & $(6)$ & $(7)$ & $(8)$ & (9) \\
\hline & & & $\begin{array}{c}0.0361 \\
(1.98)^{* *}\end{array}$ & $\begin{array}{c}0.0410 \\
(2.44)^{* *}\end{array}$ & $\begin{array}{c}0.0517 \\
(2.28)^{* *}\end{array}$ & & & & $\begin{array}{l}0.0518 \\
(1.95)^{*}\end{array}$ \\
\hline Military Experience & & & & & & $\begin{array}{l}0.0353 \\
(1.69)^{*}\end{array}$ & $\begin{array}{l}0.0326 \\
(1.92)^{*}\end{array}$ & $\begin{array}{c}-0.0015 \\
(-0.08)\end{array}$ & $\begin{array}{c}0.002 \\
(-0.09)\end{array}$ \\
\hline World War II Veteran & & & & & & & & $\begin{array}{c}0.0695 \\
(2.21)^{* *}\end{array}$ & $\begin{array}{l}0.0517 \\
(1.71)^{*}\end{array}$ \\
\hline Profitability & $\begin{array}{c}-0.7074 \\
(-5.18) * * *\end{array}$ & $\begin{array}{c}-0.4600 \\
(-6.79) * * *\end{array}$ & $\begin{array}{c}-0.4634 \\
(-6.88) * * *\end{array}$ & $\begin{array}{c}-0.2774 \\
(-3.78) * * *\end{array}$ & $\begin{array}{c}-0.3586 \\
(-4.64)^{* * *}\end{array}$ & & $\begin{array}{c}-0.3364 \\
(-3.52) * * *\end{array}$ & $\begin{array}{c}-0.3281 \\
(-3.56)^{* * *}\end{array}$ & $\begin{array}{c}-0.274 \\
(-3.60) * * *\end{array}$ \\
\hline Tangibility & $\begin{array}{c}0.1155 \\
(2.66)^{* * *}\end{array}$ & $\begin{array}{c}0.0248 \\
(0.58)\end{array}$ & $\begin{array}{c}0.0238 \\
(0.56)\end{array}$ & $\begin{array}{c}0.0265 \\
(0.63)\end{array}$ & $\begin{array}{c}0.0286 \\
(0.70)\end{array}$ & & $\begin{array}{c}-0.0062 \\
(-0.16)\end{array}$ & $\begin{array}{c}-0.0035 \\
(-0.09)\end{array}$ & $\begin{array}{l}0.0258 \\
(-0.75)\end{array}$ \\
\hline $\ln$ (Sales) & $\begin{array}{c}0.0360 \\
(4.03)^{* * *}\end{array}$ & $\begin{array}{c}0.0476 \\
(4.76)^{* * *}\end{array}$ & $\begin{array}{c}0.0491 \\
(4.92)^{* * *}\end{array}$ & $\begin{array}{c}0.0338 \\
(3.32)^{* * *}\end{array}$ & $\begin{array}{c}0.0513 \\
(4.11)^{* * *}\end{array}$ & & $\begin{array}{c}0.0418 \\
(3.07)^{* * *}\end{array}$ & $\begin{array}{c}0.0411 \\
(3.09)^{* * *}\end{array}$ & $\begin{array}{c}0.0457 \\
(3.03)^{* * *}\end{array}$ \\
\hline Q & $\begin{array}{c}-0.0424 \\
(-2.68)^{* * *}\end{array}$ & $\begin{array}{l}-0.0126 \\
(-1.86)^{*}\end{array}$ & $\begin{array}{l}-0.0119 \\
(-1.76)^{*}\end{array}$ & $\begin{array}{l}0.0028 \\
(0.40)\end{array}$ & $\begin{array}{l}0.0089 \\
(1.31)\end{array}$ & & $\begin{array}{c}-0.013 \\
(-1.92)^{*}\end{array}$ & $\begin{array}{l}-0.0132 \\
(-1.94)^{*}\end{array}$ & $\begin{array}{c}0.0172 \\
(2.88)^{* * *}\end{array}$ \\
\hline Net Financing Deficit & $\begin{array}{c}0.2438 \\
(4.14)^{* * *}\end{array}$ & $\begin{array}{c}0.1228 \\
(4.96)^{* * *}\end{array}$ & $\begin{array}{c}0.1227 \\
(4.95)^{* * *}\end{array}$ & $\begin{array}{c}0.1189 \\
(4.75)^{* * *}\end{array}$ & $\begin{array}{c}0.1238 \\
(5.20)^{* * *}\end{array}$ & & $\begin{array}{c}0.1427 \\
(4.48)^{* * *}\end{array}$ & $\begin{array}{c}0.1406 \\
(4.49)^{* * *}\end{array}$ & $\begin{array}{c}0.1047 \\
(4.55)^{* * *}\end{array}$ \\
\hline Returns $_{\mathrm{t}-1}$ & & & & $\begin{array}{c}-0.0692 \\
(-4.21)^{* * *}\end{array}$ & $\begin{array}{c}-0.0718 \\
(-4.05)^{* * *}\end{array}$ & & & & $\begin{array}{c}-0.098 \\
(-6.62)^{* * *}\end{array}$ \\
\hline Returns $_{\mathrm{t}-2}$ & & & & $\begin{array}{c}-0.056 \\
(-2.72)^{* * *}\end{array}$ & $\begin{array}{c}-0.0526 \\
(-2.38)^{* *}\end{array}$ & & & & $\begin{array}{c}-0.0835 \\
(-6.28)^{* * *}\end{array}$ \\
\hline Returns $_{\mathrm{t}-3}$ & & & & $\begin{array}{c}-0.0416 \\
(-3.54)^{* * *}\end{array}$ & $\begin{array}{c}-0.0469 \\
(-3.88)^{* * *}\end{array}$ & & & & $\begin{array}{c}-0.0604 \\
(-6.56)^{* * *}\end{array}$ \\
\hline Returns $_{\mathrm{t}-4}$ & & & & $\begin{array}{c}-0.0307 \\
(-3.48)^{* * *}\end{array}$ & $\begin{array}{c}-0.0396 \\
(-4.21)^{* * *}\end{array}$ & & & & $\begin{array}{c}-0.0546 \\
(-5.63)^{* * *}\end{array}$ \\
\hline Returns $_{\mathrm{t}-5}$ & & & & $\begin{array}{c}-0.0105 \\
(-1.30)\end{array}$ & $\begin{array}{l}-0.0176 \\
(-2.11)^{* *}\end{array}$ & & & & $\begin{array}{l}-0.0153 \\
(-1.80)^{*}\end{array}$ \\
\hline CEO Stock Ownership & & & & & $\begin{array}{c}0.1085 \\
(1.60)\end{array}$ & & & & $\begin{array}{l}0.0431 \\
(-0.94)\end{array}$ \\
\hline CEO Vested Options & & & & & $\begin{array}{c}0.1119 \\
(2.48)^{* *}\end{array}$ & & & & $\begin{array}{c}-0.0001 \\
(-0.00)\end{array}$ \\
\hline Age & & & & & & & $\begin{array}{c}0.0036 \\
(2.90) * * *\end{array}$ & $\begin{array}{c}0.0025 \\
(2.08)^{* *}\end{array}$ & $\begin{array}{c}0.0024 \\
(2.09)^{* *}\end{array}$ \\
\hline Tenure & & & & & $\begin{array}{r}-0.0007 \\
(-0.81)\end{array}$ & & $\begin{array}{c}-0.0054 \\
(-4.60)^{* * *}\end{array}$ & $\begin{array}{c}-0.0051 \\
(-4.75)^{* * *}\end{array}$ & $\begin{array}{c}-0.0044 \\
(-4.19)^{* * *}\end{array}$ \\
\hline (Tenure)*(Longholder) & & & & & $\begin{array}{l}-0.0021 \\
(-1.45)\end{array}$ & & & & \\
\hline Firm Effects & & $\mathrm{X}$ & $\mathrm{X}$ & $\mathrm{X}$ & $\mathrm{X}$ & $\mathrm{X}$ & $\mathrm{X}$ & $\mathrm{X}$ & $\mathrm{X}$ \\
\hline Year Effects & & & & & $\mathrm{X}$ & $X$ & $\mathrm{X}$ & $\mathrm{X}$ & $\mathrm{X}$ \\
\hline Observations & 2,184 & 2,184 & 2,184 & 2,184 & 2,184 & 1,626 & 1,626 & 1,626 & 1,521 \\
\hline Number of Firms & 241 & 241 & 241 & 241 & 241 & 210 & 210 & 210 & 194 \\
\hline Adjusted R-squared (W & thin) & 0.11 & 0.12 & 0.16 & 0.22 & 0.08 & 0.19 & 0.19 & 0.29 \\
\hline Adjusted R-squared & 0.35 & 0.77 & 0.77 & 0.78 & 0.80 & 0.78 & 0.80 & 0.80 & 0.83 \\
\hline
\end{tabular}

* significant at $10 \%$; ** significant at $5 \%$; *** significant at $1 \%$ 


\section{Panel A. Financing Deficit Variables}

Table A1. Summary Statistics (Execucomp Sample)

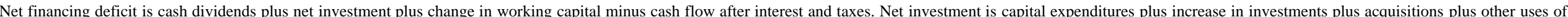

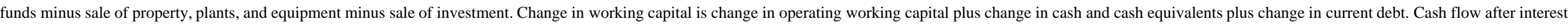

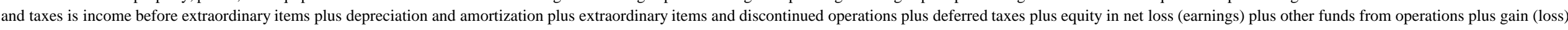

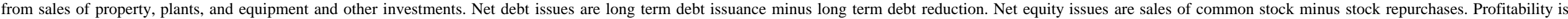

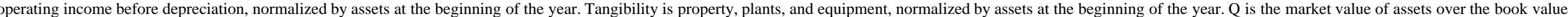
of assets, where market value of assets is the book value of assets plus market equity minus book equity. $\Delta$ denotes one-year changes.

\begin{tabular}{|c|c|c|c|c|c|c|c|c|c|c|c|c|}
\hline \multirow[b]{2}{*}{ Variable } & \multicolumn{3}{|c|}{$\begin{array}{c}\text { Number of Firms }=2,166 \\
\text { Num. Firm-Years }=13,948 \\
(\text { w/ Net Equity Issues) }=13,556\end{array}$} & \multicolumn{3}{|c|}{$\begin{array}{c}\text { Number of Firms }=270 \\
\text { Num. Firm-Years }=377 \\
\text { (w/ Net Equity Issues) }=367\end{array}$} & \multicolumn{3}{|c|}{$\begin{array}{c}\text { Number of Firms }=1,359 \\
\text { Num. Firm-Years }=7,151 \\
\text { (w/ Net Equity Issues) }=6,952\end{array}$} & \multicolumn{3}{|c|}{$\begin{array}{c}\text { Number of Firms }=763 \\
\text { Num. Firm-Years }=5,097 \\
\text { (w/ Net Equity Issues) }=4,932\end{array}$} \\
\hline & Mean & Median & SD & Mean & Median & SD & Mean & Median & SD & Mean & Median & SD \\
\hline Assets (\$m) & 5507.56 & 1112.16 & 22779.22 & 12870.27 & 2053.48 & 57899.51 & 4665.88 & 1108.21 & 15685.05 & 6879 & 1516.50 & 28433.19 \\
\hline Net Financing Deficit (\$m) & 8.44 & 0.01 & 1260.86 & 109.20 & 0.55 & 3162.61 & 4.69 & 1.72 & 945.82 & 7 & -0.24 & 1591.74 \\
\hline Net Investment (\$m) & 431.65 & 78.00 & 2038.34 & 1224.21 & 142.70 & 5352.03 & 428.15 & 93.47 & 1551.85 & 564 & 114.21 & 2370.11 \\
\hline Change in Working Capital (\$m) & 59.76 & 12.71 & 869.69 & 6.50 & 22.39 & 1092.09 & 54.89 & 15.90 & 757.65 & 75 & 16.36 & 758.64 \\
\hline Cash Flow after Interest and Taxes (\$m) & 576.36 & 119.00 & 1951.71 & 1359.42 & 258.14 & 4002.86 & 555.39 & 128.86 & 1806.95 & 753 & 177.20 & 2201.42 \\
\hline Net Financing Deficit/Assets $\mathrm{t}_{\mathrm{t}-1}$ & 0.04 & 0.00 & 0.27 & 0.03 & 0.00 & 0.25 & 0.06 & 0.00 & 0.32 & 0.03 & 0.00 & 0.22 \\
\hline Net Debt Issues/Assets $\mathrm{t}_{\mathrm{t}-1}$ & 0.03 & 0.00 & 0.18 & 0.06 & 0.00 & 0.21 & 0.04 & 0.00 & 0.20 & 0.04 & 0.00 & 0.18 \\
\hline Net Equity Issues/Assets ${ }_{t-1}$ & 0.01 & 0.00 & 0.19 & -0.03 & -0.01 & 0.12 & 0.01 & 0.00 & 0.24 & 0.00 & 0.00 & 0.12 \\
\hline Profitability & 0.16 & 0.16 & 0.15 & 0.17 & 0.17 & 0.12 & 0.18 & 0.18 & 0.16 & 0.18 & 0.17 & 0.12 \\
\hline$\Delta$ Tangibility & -0.01 & 0.00 & 0.16 & 0.00 & 0.00 & 0.13 & -0.01 & 0.00 & 0.18 & -0.01 & 0.00 & 0.16 \\
\hline Q & 2.12 & 1.61 & 1.90 & 2.17 & 1.88 & 1.21 & 2.43 & 1.85 & 2.24 & 2.20 & 1.73 & 1.57 \\
\hline$\Delta \mathrm{Q}$ & -0.12 & -0.01 & 2.16 & -0.03 & -0.03 & 0.64 & -0.11 & 0.00 & 2.27 & -0.06 & 0.00 & 1.37 \\
\hline $\ln$ (Sales) & 7.12 & 7.05 & 1.63 & 7.71 & 7.50 & 1.64 & 7.08 & 7.02 & 1.59 & 7.44 & 7.36 & 1.57 \\
\hline$\Delta \ln ($ Sales) & 0.10 & 0.09 & 0.27 & 0.10 & 0.11 & 0.23 & 0.14 & 0.12 & 0.27 & 0.12 & 0.10 & 0.22 \\
\hline \multicolumn{13}{|c|}{ Distribution across Fama French 12 Industry Groups } \\
\hline & (I) & (II) & (III) & (IV) & & & & & (I) & (II) & (III) & (IV) \\
\hline Consumer Nondurables & 0.09 & 0.06 & 0.07 & 0.09 & & & Telecomn & unication & 0.03 & 0.02 & 0.03 & 0.02 \\
\hline Consumer Durables & 0.04 & 0.02 & 0.03 & 0.04 & & & & Utilities & n.a. & n.a. & n.a. & n.a. \\
\hline Manufacturing & 0.13 & 0.07 & 0.10 & 0.12 & & & & Shops & 0.15 & 0.16 & 0.14 & 0.16 \\
\hline Energy & 0.05 & 0.09 & 0.06 & 0.07 & & & & Health & 0.10 & 0.14 & 0.13 & 0.11 \\
\hline Chemicals and Allied Products & 0.05 & 0.02 & 0.03 & 0.05 & & & & Money & n.a. & n.a. & n.a. & n.a. \\
\hline Business Equipment & 0.20 & 0.20 & 0.24 & 0.17 & & & & Other & 0.17 & 0.21 & 0.17 & 0.17 \\
\hline
\end{tabular}

The Fama-French Industry Groups are defined on French's website (http://mba.tuck.dartmouth.edu/pages/faculty/ken.french/data_library.html). 


\section{Table A1 (cont.)}

Kink is the amount of interest at the point where the marginal benefit function becomes downward sloping, as a proportion of actual interest expense. ECOST is the standard deviation of the first difference in taxable earnings divided by assets, the quoteient times the sum of advertising, research, and development expenses divided by sales. CYCLICAL is the standard deviation of operating earnings divided by mean assets first calculated for each firm, then averaged across firms within two-digit SIC codes. Return on assets is income before extraordinary items plus interest expense plus depreciation, divided by assets. Z-score is 3.3 times the difference of operating income before depreciation and depreciation plus sales plus 1.4 times retained earnings plus 1.2 times working capital (balance sheet), the quantity divided by assets. Quick ratio is the sum of cash and short-term investments and total receivables divided by total current liabilities. Current ratio is total current assets divided by total current liabilities. Q-ratio is preferred stock plus market value of common equity plus net short-term liabilities, the quantity divided by assets. R\&D to sales and Advertising to sales are set to 0 when the numerator is missing. Computer Industry are all firms with SIC code 357, Semiconductor Industry all firms with SIC code 367, Chemicals and Allied Products comprises SIC codes 280-289, Aircraft and Guided Space Vehicles SIC codes 372 and 376, and Other Sensitive Industries SIC codes 340-400, excluding 357, 367, 372, and 376. Vested options (as a \% of shares outstanding) are multiplied by 10 so that the means of vested options and stock ownership are the same order of magnitude.

\begin{tabular}{|c|c|c|c|c|c|c|c|c|c|c|c|c|}
\hline \multirow[b]{2}{*}{ Variable } & \multicolumn{3}{|c|}{$\begin{array}{c}(\mathrm{I}) \\
\text { Number of Firms }=1,485 \\
\text { Num. Firm-Years }=8,730\end{array}$} & \multicolumn{3}{|c|}{$\begin{array}{c}\text { (II) } \\
\text { Number of Firms }=194 \\
\text { Num. Firm-Years }=278\end{array}$} & \multicolumn{3}{|c|}{$\begin{array}{c}\text { (III) } \\
\text { Number of Firms }=914 \\
\text { Num. Firm-Years }=4,413\end{array}$} & \multicolumn{3}{|c|}{$\begin{array}{c}\text { (IV) } \\
\text { Number of Firms }=613 \\
\text { Num. Firm-Years }=3,599\end{array}$} \\
\hline & Mean & Median & SD & Mean & Median & SD & Mean & Median & SD & Mean & Median & SD \\
\hline Kink & 4.23 & 3 & 3.44 & 5.28 & 5 & 3.55 & 4.56 & 4 & 3.43 & 4.48 & 4 & 3.35 \\
\hline I(No dividend) & 0.37 & 0 & 0.48 & 0.44 & 0 & 0.50 & 0.45 & 0 & 0.50 & 0.34 & 0 & 0.47 \\
\hline I(Negative owners' equity) & 0.02 & 0 & 0.15 & 0.01 & 0 & 0.08 & 0.02 & 0 & 0.13 & 0.01 & 0 & 0.08 \\
\hline I(NOL carryforward) & 0.33 & 0 & 0.47 & 0.47 & 0 & 0.50 & 0.32 & 0 & 0.47 & 0.31 & 0 & 0.46 \\
\hline ECOST & 3.58 & 0.45 & 10.15 & 3.97 & 0.35 & 10.65 & 4.33 & 0.59 & 11.18 & 3.22 & 0.44 & 9.07 \\
\hline CYCLICAL & 0.09 & 0.10 & 0.03 & 0.10 & 0.10 & 0.03 & 0.09 & 0.10 & 0.02 & 0.09 & 0.10 & 0.03 \\
\hline Return on assets & 0.11 & 0.12 & 0.10 & 0.12 & 0.12 & 0.08 & 0.12 & 0.13 & 0.09 & 0.12 & 0.12 & 0.07 \\
\hline $\ln$ (sales) & 7.39 & 7.32 & 1.50 & 7.77 & 7.55 & 1.53 & 7.36 & 7.30 & 1.48 & 7.66 & 7.56 & 1.44 \\
\hline Z-score & 2.09 & 2.13 & 1.39 & 2.14 & 2.09 & 1.19 & 2.15 & 2.21 & 1.37 & 2.27 & 2.22 & 1.14 \\
\hline Quick ratio & 1.44 & 1.04 & 1.44 & 1.48 & 1.07 & 1.42 & 1.56 & 1.12 & 1.59 & 1.42 & 1.03 & 1.46 \\
\hline Current ratio & 2.22 & 1.80 & 1.62 & 2.22 & 1.70 & 1.61 & 2.31 & 1.87 & 1.73 & 2.18 & 1.78 & 1.64 \\
\hline PPE-to-assets & 0.32 & 0.27 & 0.21 & 0.26 & 0.19 & 0.23 & 0.30 & 0.24 & 0.21 & 0.31 & 0.26 & 0.21 \\
\hline Q-ratio & 1.46 & 1.12 & 1.24 & 1.64 & 1.34 & 1.10 & 1.72 & 1.31 & 1.37 & 1.62 & 1.24 & 1.28 \\
\hline R\&D-to-sales & 0.04 & 0 & 0.12 & 0.06 & 0 & 0.15 & 0.05 & 0.00 & 0.13 & 0.04 & 0 & 0.10 \\
\hline Advertising-to-sales & 0.01 & 0 & 0.03 & 0.01 & 0 & 0.03 & 0.01 & 0 & 0.02 & 0.01 & 0 & 0.02 \\
\hline Computer Industry & 0.02 & 0 & 0.15 & 0.01 & 0 & 0.12 & 0.03 & 0 & 0.16 & 0.02 & 0 & 0.13 \\
\hline Semiconductor Industry & 0.04 & 0 & 0.20 & 0.06 & 0 & 0.23 & 0.06 & 0 & 0.24 & 0.05 & 0 & 0.21 \\
\hline Chemicals and Allied Products Industry & 0.10 & 0 & 0.30 & 0.09 & 0 & 0.29 & 0.10 & 0 & 0.30 & 0.12 & 0 & 0.32 \\
\hline Aircraft and Guided Space Vehicles Industry & 0.01 & 0 & 0.11 & 0.01 & 0 & 0.10 & 0.01 & 0 & 0.11 & 0.01 & 0 & 0.11 \\
\hline Other Sensitive Industries & 0.22 & 0 & 0.41 & 0.21 & 0 & 0.40 & 0.23 & 0 & 0.42 & 0.21 & 0 & 0.41 \\
\hline
\end{tabular}

\section{Panel C. CEO Variables}

CEO Vested Options are the CEO's holdings of options that are exercisable within 6 months of the beginning of the year (as a \% of shares outstanding), multiplied by 10 so that the means of vested options and CEO Stock Ownership are the same order of magnitude. Depression Baby is an indicator variable for CEOs born in the 1920s. Military Experience indicates CEOs with prior military service.

\begin{tabular}{|c|c|c|c|c|c|c|c|c|c|c|c|c|}
\hline \multirow[b]{2}{*}{ Variable } & \multicolumn{3}{|c|}{$\begin{array}{c}\text { (I) } \\
\text { Number of CEOs }=3,466\end{array}$} & \multicolumn{3}{|c|}{$\begin{array}{c}\text { (II) } \\
\text { Number of CEOs }=270\end{array}$} & \multicolumn{3}{|c|}{$\begin{array}{c}\text { (III) } \\
\text { Number of CEOs }=1,579\end{array}$} & \multicolumn{3}{|c|}{$\begin{array}{c}\text { (IV) } \\
\text { Number of CEOs }=869\end{array}$} \\
\hline & Mean & Median & $\mathrm{SD}$ & Mean & Median & $\mathrm{SD}$ & Mean & Median & $\mathrm{SD}$ & Mean & Median & $\mathrm{SD}$ \\
\hline Age & 56.12 & 56 & 7.63 & 56.75 & 56 & 6.73 & 56.03 & 56 & 7.40 & 55.92 & 56 & 6.93 \\
\hline Tenure & 9.13 & 7 & 7.81 & 11.28 & 9 & 7.95 & 10.27 & 8 & 7.84 & 10.05 & 8 & 7.63 \\
\hline CEO Stock Ownership & 0.03 & 0.00 & 0.07 & 0.02 & 0.00 & 0.06 & 0.03 & 0.01 & 0.06 & 0.02 & 0.00 & 0.05 \\
\hline CEO Vested Options & 0.01 & 0.00 & 0.01 & 0.01 & 0.01 & 0.01 & 0.01 & 0.01 & 0.01 & 0.01 & 0.01 & 0.01 \\
\hline Depression Baby & 0.10 & 0 & 0.30 & n.a. & n.a. & n.a. & 0.09 & 0 & 0.29 & 0.09 & 0 & 0.29 \\
\hline Military Experience & 0.04 & 0 & 0.18 & 0.01 & 0 & 0.09 & 0.03 & 0 & 0.17 & 0.02 & 0 & 0.14 \\
\hline
\end{tabular}




\section{Table A2. Alternative Longholder Measures (Execucomp Sample)}

The sample consists of S\&P 1500 companies covered by Compustat's Execucomp database between 1992 and 2007, excluding financial companies (SIC 6000-6999) and regulated utilities (SIC 4900-4999). Longholder_Exec is is a binary variable where 1 signifies that the CEO at some point during his tenure held an option package until the last year before expiration, provided that the package was at least $40 \%$ in the money entering its last year. Longholder_Thomson is a binary indicator defined as Longholder_Exec, but using Thomson Financial data to identify option exercises which occur in the final year of the option's duration. Longholder_Thomson is 0 for CEOs for whom we observe at least one option exercise in the Thomson database during the sample period. Longholder_Thomson_Fill is defined as Longholder_Thomson, but includes all CEOs who do not satisfy the Longholder criteria in the control group. Longholder_CJRS is a binary indicator set to one if the CEO at least twice during his tenure in the sample was holding options with average moneyness greater than $67 \%$ at the end of a fiscal year, starting in the first year the CEO displays the behavior. Returns ${ }_{\mathrm{x}}$ are the natural logarithm of 1 plus stock returns (excluding dividends) from year $\mathrm{x}$-1 to $\mathrm{x}$.

\section{Panel A. Summary Statistics}

\begin{tabular}{lccc}
\hline \hline & & $\begin{array}{c}\text { \% Over- } \\
\text { confident }\end{array}$ & $\begin{array}{c}\text { \% Not Over- } \\
\text { confident }\end{array}$ \\
\hline Longholder_Exec & 3,566 & 22.18 & 77.82 \\
Longholder_CJRS & 19,108 & 49.45 & 50.55 \\
Longholder_Thomson & 12,970 & 53.56 & 46.44 \\
Longholder_Thomson_Fill & 21,549 & 32.24 & 67.76 \\
\hline \hline
\end{tabular}

Panel B. Pairwise Correlations

\begin{tabular}{|c|c|c|c|c|c|c|c|c|c|}
\hline & $\begin{array}{c}\text { Longholder } \\
\text { _Exec }\end{array}$ & $\begin{array}{c}\text { Longholder } \\
\text { _CJRS }\end{array}$ & $\begin{array}{c}\text { Longholder } \\
\text { _Thomson }\end{array}$ & $\begin{array}{c}\text { Longholder } \\
\text { _Thomson_ } \\
\text { Fill }\end{array}$ & Returns $_{\mathrm{t}-1}$ & Returns $_{\mathrm{t}-2}$ & Returns $_{\mathrm{t}-3}$ & Returns $_{\mathrm{t}-4}$ & Returns $_{\mathrm{t}-5}$ \\
\hline Longholder_Exec & 1 & & & & & & & & \\
\hline Longholder_CJRS & $\begin{array}{c}0.2208 \\
(0.00 ; 3314)\end{array}$ & $\begin{array}{c}1 \\
(-; 19108)\end{array}$ & & & & & & & \\
\hline Longholder_Thomson & $\begin{array}{c}0.4375 \\
(0.00 ; 2290)\end{array}$ & $\begin{array}{c}0.1671 \\
(0.00 ; 12398)\end{array}$ & $\begin{array}{c}1 \\
(-; 12970)\end{array}$ & & & & & & \\
\hline Longholder_Thomson_Fill & $\begin{array}{c}0.4840 \\
(0.00 ; 3566)\end{array}$ & $\begin{array}{c}0.2678 \\
(0.00 ; 19108)\end{array}$ & $\begin{array}{c}1 \\
(-; 12970)\end{array}$ & $\begin{array}{c}1 \\
(-; 21549)\end{array}$ & & & & & \\
\hline Returns $_{\mathrm{t}-1}$ & $\begin{array}{c}0.0498 \\
(0.00 ; 3526)\end{array}$ & $\begin{array}{c}0.1517 \\
(0.00 ; 18980)\end{array}$ & $\begin{array}{c}0.0314 \\
(0.00 ; 12870)\end{array}$ & $\begin{array}{c}0.0723 \\
(0.00 ; 21298)\end{array}$ & $\begin{array}{c}1 \\
(-; 28944)\end{array}$ & & & & \\
\hline Returns $_{\mathrm{t}-2}$ & $\begin{array}{c}0.0202 \\
(0.23 ; 3495)\end{array}$ & $\begin{array}{c}0.1684 \\
(0.00 ; 18706)\end{array}$ & $\begin{array}{c}0.0167 \\
(0.06 ; 12719)\end{array}$ & $\begin{array}{c}0.0581 \\
(0.00 ; 20939)\end{array}$ & $\begin{array}{c}-0.0227 \\
(0.00 ; 27801)\end{array}$ & $\begin{array}{c}1 \\
(-; 27848)\end{array}$ & & & \\
\hline Returns $_{\mathrm{t}-3}$ & $\begin{array}{c}0.0379 \\
(0.03 ; 3454)\end{array}$ & $\begin{array}{c}0.1629 \\
(0.00 ; 18285)\end{array}$ & $\begin{array}{c}0.0169 \\
(0.06 ; 12484)\end{array}$ & $\begin{array}{c}0.0523 \\
(0.00 ; 20429)\end{array}$ & $\begin{array}{c}-0.0538 \\
(0.00 ; 26644)\end{array}$ & $\begin{array}{c}-0.0498 \\
(0.00 ; 26691)\end{array}$ & $\begin{array}{c}1 \\
(-; 26470)\end{array}$ & & \\
\hline Returns $_{\mathrm{t}-4}$ & $\begin{array}{c}0.0145 \\
(0.40 ; 3420)\end{array}$ & $\begin{array}{c}0.1303 \\
(0.00 ; 17760)\end{array}$ & $\begin{array}{c}0.021 \\
(0.02 ; 12175)\end{array}$ & $\begin{array}{c}0.0508 \\
(0.00 ; 19809)\end{array}$ & $\begin{array}{c}-0.0613 \\
(0.00 ; 25484)\end{array}$ & $\begin{array}{c}-0.0622 \\
(0.00 ; 25520)\end{array}$ & $\begin{array}{c}-0.0488 \\
(0.00 ; 25568)\end{array}$ & $\begin{array}{c}1 \\
(-; 25624)\end{array}$ & \\
\hline Returns $_{\mathrm{t}-5}$ & $\begin{array}{c}0.0103 \\
(0.55 ; 3385)\end{array}$ & $\begin{array}{c}0.0897 \\
(0.00 ; 17172) \\
\end{array}$ & $\begin{array}{c}0.0345 \\
(0.00 ; 11799)\end{array}$ & $\begin{array}{c}0.0518 \\
(0.00 ; 19129) \\
\end{array}$ & $\begin{array}{c}0.004 \\
(0.54 ; 24305)\end{array}$ & $\begin{array}{c}-0.0744 \\
(0.00 ; 24326)\end{array}$ & $\begin{array}{c}-0.0716 \\
(0.00 ; 24360)\end{array}$ & $\begin{array}{c}-0.0561 \\
(0.00 ; 24413)\end{array}$ & $\begin{array}{c}1 \\
(-; 24478)\end{array}$ \\
\hline
\end{tabular}

p-values and number of observations in parentheses 
Logit regressions with coefficients reported as log odds ratios. The dependent variable is binary and equals 1 if the firm issued equity during the fiscal year. The sample consists of all firm years in which the firm did at least one public security issue for S\&P 1500 firms included in Compustat's Execucomp database between 1992 and 2007 excluding financial firms (SIC 6000-6999) and regulated utilities (SIC 4900-4999). CEO Stock Ownership is the number of shares owned by the CEO excluding options. CEO Vested Options is the CEO's holdings of unexercised exercisable stock options, multiplied by 10 (so that the mean is roughly comparable to CEO Stock Ownership). CEO Stock Ownership and CEO Vested Options are scaled by common shares outstanding and are measured at the beginning of the fiscal year. Longholder_Exec is is a binary variable where 1 signifies that the CEO at some point during his tenure held an option package until the last year before expiration, provided that the package was at least $40 \%$ in the money entering its last year. Longholder_Thomson is a binary indicator defined as Longholder_Exec, but using Thomson Financial data to identify option exercises which occur in the final year of the option's duration. Longholder_Thomson is 0 for CEOs for whom we observe at least one option exercise in the Thomson database during the sample period. Longholder_Thomson_Fill is defined as Longholder_Thomson, but includes all CEOs who do not satisfy the Longholder criteria in the control group. Longholder_CJRS is a binary indicator set to one if the CEO at least twice during his tenure in the sample was holding options with average moneyness greater than $67 \%$ at the end of a fiscal year, starting in the first year the CEO displays the behavior. Return Controls are the natural logarithms of 1 plus annual stock returns (excluding dividends) over the five prior fiscal years. Standard firm controls, book leverage, kink controls, and industry fixed effects are as defined in Table III, Panel B. All standard errors are adjusted for clustering at the firm level.

\begin{tabular}{|c|c|c|c|c|c|c|}
\hline & $(1)$ & $(2)$ & (3) & (4) & (5) & (6) \\
\hline & \multicolumn{6}{|c|}{ Panel A. Longholder_Exec } \\
\hline Longholder_Exec & $\begin{array}{l}-0.5854 \\
(1.79)^{*}\end{array}$ & $\begin{array}{l}-1.1084 \\
(2.54)^{* *}\end{array}$ & $\begin{array}{c}-0.9629 \\
(2.50)^{* *}\end{array}$ & $\begin{array}{l}-0.9203 \\
(2.34)^{* *}\end{array}$ & $\begin{array}{l}-0.9361 \\
(2.16)^{* *}\end{array}$ & $\begin{array}{l}-1.2997 \\
(2.33)^{* *}\end{array}$ \\
\hline CEO Stock Ownership & & $\begin{array}{c}15.2343 \\
(3.08)^{* * *}\end{array}$ & $\begin{array}{c}10.2797 \\
(2.87)^{* * *}\end{array}$ & $\begin{array}{c}10.4621 \\
(2.89)^{* * *}\end{array}$ & $\begin{array}{l}7.3521 \\
(1.47)\end{array}$ & $\begin{array}{c}10.3829 \\
(1.77)^{*}\end{array}$ \\
\hline CEO Vested Options & & $\begin{array}{c}5.21 \\
(2.55)^{* *}\end{array}$ & $\begin{array}{c}1.68201 \\
(0.91)\end{array}$ & $\begin{array}{c}1.45963 \\
(0.78)\end{array}$ & $\begin{array}{l}1.6262 \\
(0.79)\end{array}$ & $\begin{array}{c}0.92258 \\
(0.36)\end{array}$ \\
\hline \multirow[t]{2}{*}{ Observations } & 361 & 297 & 293 & 282 & 269 & 226 \\
\hline & \multicolumn{6}{|c|}{ Panel B. Longholder_CJRS } \\
\hline Longholder_CJRS & $\begin{array}{c}0.3243 \\
(3.82)^{* * *}\end{array}$ & $\begin{array}{c}0.2057 \\
(2.00)^{* *}\end{array}$ & $\begin{array}{c}-0.0021 \\
(0.02)\end{array}$ & $\begin{array}{c}0.0022 \\
(0.02)\end{array}$ & $\begin{array}{c}-0.3273 \\
(2.50)^{* *}\end{array}$ & $\begin{array}{c}-0.4304 \\
(2.78)^{* * *}\end{array}$ \\
\hline CEO Stock Ownership & & $\begin{array}{c}4.6172 \\
(4.77)^{* * *}\end{array}$ & $\begin{array}{c}2.2825 \\
(2.70)^{* * *}\end{array}$ & $\begin{array}{c}2.1641 \\
(2.62)^{* * *}\end{array}$ & $\begin{array}{l}1.6315 \\
(1.52)\end{array}$ & $\begin{array}{l}1.6771 \\
(1.21)\end{array}$ \\
\hline CEO Vested Options & & $\begin{array}{c}1.45164 \\
(2.98)^{* * *}\end{array}$ & $\begin{array}{c}-0.02549 \\
(0.06)\end{array}$ & $\begin{array}{c}0.10186 \\
(0.24)\end{array}$ & $\begin{array}{c}0.0658 \\
(0.15)\end{array}$ & $\begin{array}{l}0.5303 \\
(0.82)\end{array}$ \\
\hline \multirow[t]{2}{*}{ Observations } & 3,552 & 2,648 & 2,615 & 2,539 & 2,276 & 1,773 \\
\hline & \multicolumn{6}{|c|}{ Panel C. Longholder_Thomson } \\
\hline Longholder_Thomson & $\begin{array}{c}-0.5377 \\
(4.95)^{* * *}\end{array}$ & $\begin{array}{c}-0.5083 \\
(4.00)^{* * *}\end{array}$ & $\begin{array}{l}-0.3011 \\
(2.30)^{* *}\end{array}$ & $\begin{array}{l}-0.3036 \\
(2.26)^{* *}\end{array}$ & $\begin{array}{l}-0.2401 \\
(1.67)^{*}\end{array}$ & $\begin{array}{c}-0.2355 \\
(1.35)\end{array}$ \\
\hline CEO Stock Ownership & & $\begin{array}{c}4.9631 \\
(3.64)^{* * *}\end{array}$ & $\begin{array}{c}2.929 \\
(2.73)^{* * *}\end{array}$ & $\begin{array}{c}2.8806 \\
(2.57)^{* *}\end{array}$ & $\begin{array}{l}2.2132 \\
(1.83)^{*}\end{array}$ & $\begin{array}{l}2.2235 \\
(1.52)\end{array}$ \\
\hline CEO Vested Options & & $\begin{array}{c}2.00796 \\
(3.35)^{* * *}\end{array}$ & $\begin{array}{c}0.25694 \\
(0.51)\end{array}$ & $\begin{array}{c}0.38396 \\
(0.73)\end{array}$ & $\begin{array}{c}0.20277 \\
(0.38)\end{array}$ & $\begin{array}{c}0.74639 \\
(0.83)\end{array}$ \\
\hline \multirow[t]{2}{*}{ Observations } & 2,568 & 1,991 & 1,970 & 1,921 & 1,776 & 1,373 \\
\hline & \multicolumn{6}{|c|}{ Panel D. Longholder_Thomson_Fill } \\
\hline Longholder_Thomson_Fill & $\begin{array}{c}-0.6344 \\
(6.78)^{* * *}\end{array}$ & $\begin{array}{c}-0.5764 \\
(5.27)^{* * *}\end{array}$ & $\begin{array}{c}-0.3728 \\
(3.38)^{* * *}\end{array}$ & $\begin{array}{c}-0.3606 \\
(3.17)^{* * *}\end{array}$ & $\begin{array}{c}-0.3405 \\
(2.79)^{* * *}\end{array}$ & $\begin{array}{l}-0.3622 \\
(2.49)^{* *}\end{array}$ \\
\hline CEO Stock Ownership & & $\begin{array}{c}5.0850 \\
(5.70)^{* * *}\end{array}$ & $\begin{array}{c}2.7279 \\
(3.78)^{* * *}\end{array}$ & $\begin{array}{c}2.6052 \\
(3.59)^{* * *}\end{array}$ & $\begin{array}{c}1.9706 \\
(2.21)^{* *}\end{array}$ & $\begin{array}{l}1.5942 \\
(1.35)\end{array}$ \\
\hline CEO Vested Options & & $\begin{array}{c}1.6251 \\
(3.32)^{* * *}\end{array}$ & $\begin{array}{c}0.00965 \\
(0.02)\end{array}$ & $\begin{array}{c}0.12202 \\
(0.29)\end{array}$ & $\begin{array}{c}-0.06323 \\
(0.14)\end{array}$ & $\begin{array}{c}0.25244 \\
(0.39)\end{array}$ \\
\hline Observations & 3,960 & 2,822 & 2,788 & 2,705 & 2,393 & 1,840 \\
\hline Standard firm controls & & & $\mathrm{X}$ & $\mathrm{X}$ & $\mathrm{X}$ & \\
\hline Book leverage & & & & $\mathrm{X}$ & $\mathrm{X}$ & \\
\hline Kink controls & & & & & & $\mathrm{X}$ \\
\hline Return controls & & & & & $\mathrm{X}$ & $\mathrm{X}$ \\
\hline Industry fixed effects & & & & & & $\mathrm{X}$ \\
\hline Year fixed effects & & & & $\mathrm{X}$ & $X$ & $\mathrm{X}$ \\
\hline
\end{tabular}

* significant at $10 \%$, ** significant at $5 \%, * * *$ significant at $1 \%$ 


\title{
Online Appendix \\ to \\ Managerial Beliefs and Corporate Financial Policies
}

\author{
Ulrike Malmendier \\ UC Berkeley and NBER \\ Geoffrey Tate \\ ulrike@econ.berkeley.edu \\ UCLA \\ geoff.tate@anderson.ucla.edu \\ Jon Yan \\ Stanford \\ jonathan.yan@stanford.edu
}

December 1, 2010 
In this Online Appendix, we provide a simple theoretical framework to examine the capital structure predictions of one specific variation in managerial beliefs: CEO (over-)confidence. The model formalizes the hypothesis development of the main paper and helps to clarify the more subtle predictions such as the conditions under which the preference of overconfident CEOs for debt over equity are reversed.

We define overconfidence as the overestimation of mean future cash flows. The emphasis on the mean distinguishes our approach from previous theoretical literature on overconfidence. Hackbarth (forthcoming) models the underestimation of variance to generate different capitalstructure implications. Heaton (2002) models an upward shift in the probability of the good (high cash flow) state, which does not disentangle which theoretcial results are generated by the implied bias in means and which by the implied bias in variance. Relatedly, one theoretical contribution of our paper lies in showing that the overestimation of cash flows in non-default states (i.e. overvaluation of the residual claim) generates a preference between risky debt and equity. The modeling approach of Heaton (shift in probabilities) does not allow for this mechanism.

We abstract from market frictions like agency costs and asymmetric information. However, such factors do not change our predictions as long as they affect managers uniformly and are not sufficient to create boundary solutions (e.g. full debt financing for a rational CEO).

We consider a manager's decision to undertake and finance a single, non-scalable investment project with cost $I$ and stochastic return $\tilde{R}$, given by $R_{G}$ with probability $p \in(0 ; 1)$ and $R_{B}$ with probability $1-p$, where $R_{G}>I>R_{B}$. The investment cost and the return distribution are common knowledge. To fix the rational capital-structure choice, we allow for two frictions, taxes and bankruptcy costs. The firm pays a marginal rate $\tau$ on the net return $\tilde{R}-I$ if $\tilde{R}>I$ and incurs a deadweight loss $L$ in the case of bankruptcy. We assume perfectly competitive debt and equity markets and normalize the risk-free interest rate to zero. The firm has existing assets $A$ and internal funds $C$. The CEO maximizes the perceived value of the company to existing shareholders. Note that a shareholder-value maximizing CEO never buys back shares since it is a zero-sum game from the perspective of shareholders: Some current shareholders are helped at the expense of other current shareholders. We allow for the possibility that the CEO overestimates (after-tax) project returns $\tilde{R}-\tau 1_{\{R>I\}}(\tilde{R}-I): \hat{E}[\cdot]>E[\cdot]$. He may also overestimate the value of assets in place $A, \widehat{A}>A$. 
We proceed in two steps. We first consider the unconditional choice between internal and external financing. We then condition on accessing external financing and analyze the choice between risky debt and equity.

Starting from the unconditional choice between internal and external financing, we first compare using cash and riskless debt, denoted by $c \leq C$, to using equity. (Later, we consider the possibility that the CEO exhausts cash and riskless debt capacity, creating a choice between risky debt and equity.) We assume that the firm has $s>0$ shares outstanding and denote by $s^{\prime} \geq 0$ the number of new shares issued as part of the financing plan. We also assume that the bias in the CEO's expectation of project returns and in his valuation of existing assets does not depend on $c .^{1}$

Proposition 1 Overconfident CEOs strictly prefer internal finance to equity and use weakly more internal financing than rational CEOs.

Proof. The participation constraint of new shareholders to provide equity financing is

$$
\frac{s^{\prime}}{s+s^{\prime}}\left(E\left[\tilde{R}-\tau \mathbf{1}_{\{R>I\}}(\tilde{R}-I)\right]+A+C-c\right)=I-c
$$

Thus, the manager's perception of the value of current shareholders' claims after equity financing is

$$
\begin{aligned}
G & =\left(1-\frac{s^{\prime}}{s+s^{\prime}}\right)\left(\widehat{E}\left[\tilde{R}-\tau \mathbf{1}_{\{R>I\}}(\tilde{R}-I)\right]+\widehat{A}+C-c\right) \\
& =\frac{\widehat{E}\left[\tilde{R}-\tau \mathbf{1}_{\{R>I\}}(\tilde{R}-I)\right]+\widehat{A}+C-c}{E\left[\tilde{R}-\tau \mathbf{1}_{\{R>I\}}(\tilde{R}-I)\right]+A+C-c}\left(E\left[\tilde{R}-\tau \mathbf{1}_{\{R>I\}}(\tilde{R}-I)\right]+A+C-I\right)
\end{aligned}
$$

Then

$$
\begin{aligned}
\frac{\partial G}{\partial c}= & \frac{\left(\widehat{E}\left[\tilde{R}-\tau \mathbf{1}_{\{R>I\}}(\tilde{R}-I)\right]-E\left[\tilde{R}-\tau \mathbf{1}_{\{R>I\}}(\tilde{R}-I)\right]\right)+(\widehat{A}-A)}{\left(E\left[\tilde{R}-\tau \mathbf{1}_{\{R>I\}}(\tilde{R}-I)\right]+A+C-c\right)^{2}} \\
& \left(E\left[\tilde{R}-\tau \mathbf{1}_{\{R>I\}}(\tilde{R}-I)\right]+A+C-I\right)
\end{aligned}
$$

Notice that the numerator of the fraction is zero if the CEO is rational, $\hat{E}[\cdot]=E[\cdot]$ and $\widehat{A}=A$, and that it is positive for overconfident CEOs by the definition of overconfidence.

\footnotetext{
${ }^{1}$ Formally, we assume $\frac{\partial}{\partial c} \hat{E}\left[\tilde{R}-\tau 1_{\{R>I\}}(\tilde{R}-I)\right]=0$ and $\frac{\partial}{\partial c} \widehat{A}=0$.
} 
Hence, $\frac{\partial G}{\partial c}=0$ for unbiased CEOs, and $\frac{\partial G}{\partial c}>0$ for overconfident CEOs if and only if $E[\tilde{R}-$ $\left.\tau 1_{\{R>I\}}(\tilde{R}-I)\right]+A+C-I>0$. That is, as long as firm value is positive, an overconfident CEO maximizes the perceived value on $c \in[0, I]$ by setting the internal financing $c$ as high as possible. A rational CEO, instead, is indifferent among all financing plans and, hence, uses weakly less internal funding than overconfident CEOs. Q.E.D.

The intuition for Proposition 1 is that overconfident CEOs perceive the price investors are willing to pay for new issues $s^{\prime}$ to be too low since they believe markets underestimate future returns. This logic immediately extends to the CEO's preference between internal finance (if available) and risky debt if the CEO overestimates cash flows in the default state $\left(R_{B}\right)$ : Since he overestimates cash flows going to creditors, he perceives interest payments on debt to be too high. Thus, overconfident CEOs have a strict preference for internal financing over any form of external finance and exhaust cash reserves and riskless debt capacity before issuing risky securities.

Next, we analyze the choice between the two types of risky external financing, risky debt and equity, conditional on accessing external capital markets. From Proposition 1, overconfident CEOs will exhaust all cash and riskless debt capacity before raising risky capital. Thus, for simplicity, we set cash and existing assets (which can be collateralized) equal to $0, \widehat{A}=A=$ $C=0$. Conditional on implementing the project, the resulting maximization problem is:

$$
\begin{aligned}
\max _{\mathrm{d}, \mathrm{s}} & \frac{s}{s+s^{\prime}} \hat{E}\left[\left(\tilde{R}-\tau \mathbf{1}_{\{R>I\}}(\tilde{R}-I-[w-d])-w\right)^{+}\right] \\
\text {s.t. } & \frac{s^{\prime}}{s+s^{\prime}} E\left[\left(\tilde{R}-\tau \mathbf{1}_{\{R>I\}}(\tilde{R}-I-[w-d])-w\right)^{+}\right]=I-d \\
& E[\min \{w, \tilde{R}-L\}]=d \\
& R_{B} \leq d \leq I
\end{aligned}
$$

where $w$ is the face value of debt, $d$ the market value of debt, and $L$ the deadweight loss from bankruptcy. Interest payments $w-d$ are tax deductible. The CEO maximizes the perceived expected returns accruing to current shareholders after subtracting taxes and repaying debt. Constraints (2) and (3) are the participation constraints for new shareholders and lenders, respectively. Note that the compensation required for equity and debt financing depends on investors' unbiased beliefs rather than managerial perception. Condition (4) reflects that we are considering the case of risky debt, i. e., the choice between debt and equity after exhausting 
all riskless debt capacity created by the project.

The following Proposition characterizes the financing choice of rational CEOs $(\hat{E}[\cdot]=E[\cdot])$ :

Proposition 2 Rational CEOs finance the risky portion of investment, $I-R_{B}$, using only risky debt if the tax benefits are high relative to bankruptcy costs, $\frac{\tau\left(I-R_{B}\right)}{1-\tau}>L$. They use only equity if the tax benefits are low relative to bankruptcy costs, $\frac{\tau\left(I-R_{B}\right)}{1-\tau}<L$. They are indifferent if $\frac{\tau\left(I-R_{B}\right)}{1-\tau}=L$.

Proof. For notational simplicity, define $Q \equiv E\left[\left(\tilde{R}-\tau 1_{\{R>I\}}(\tilde{R}-I-[w-d])-w\right)^{+}\right]$. Using the participation constraint for shareholders (2) and the fact that $E[\cdot]=\hat{E}[\cdot]$ for rational CEOs, we can re-write the maximand as $Q-(I-d)$. We consider separately the case in which the CEO uses at least some risky debt $\left(w>d>R_{B}\right)$ and the case in which the CEO uses no risky debt, $w=d=R_{B}$. The latter case is the lower boundary of (4).

In the first case, i.e. if $w>R_{B}$, the firm defaults in the bad state and, hence $\mathrm{Q}$ becomes

$$
\begin{aligned}
Q & =(1-\tau) p R_{G}+p \tau I-(1-\tau) p w-p \tau d \\
\Longleftrightarrow Q-(I-d) & =(1-\tau) p R_{G}-(1-p \tau) I-(1-\tau) p w+(1-p \tau) d .
\end{aligned}
$$

Using (3) to substitute for $w$, the maximand $Q-(I-d)$ becomes:

$$
Q-(I-d)=(1-\tau) p R_{G}-(1-p \tau) I+(1-\tau)(1-p)\left(R_{B}-L\right)+\tau(1-p) d .
$$

Since $d$ enters positively, value is maximized by setting $d$ as high as possible. Thus, given boundary (4), the optimal level of debt is $d^{*}=I$. Substituting back into the maximand yields

$$
Q-\left(I-d^{*}\right)=(1-\tau)\left[p R_{G}+(1-p)\left(R_{B}-L\right)-I\right]
$$

In the second case, $w=R_{B}$, the firm uses only riskless debt and equity. Thus, there is no default, and we have:

$$
\begin{aligned}
Q & =(1-\tau) p R_{G}+p \tau I+(1-p) R_{B}-d \\
\Longleftrightarrow Q-(I-d) & =(1-\tau) p R_{G}-(1-p \tau) I+(1-p) R_{B}
\end{aligned}
$$


Comparing the value function at the two boundaries, we find that the manager will choose full debt financing if:

$$
(1-\tau)\left[p R_{G}+(1-p)\left(R_{B}-L\right)-I\right]>(1-\tau) p R_{G}-(1-p \tau) I+(1-p) R_{B}
$$

which simplifies to $\frac{\tau\left(I-R_{B}\right)}{1-\tau}>L$. For the reverse inequality, the manager will choose full equity financing, and he is indifferent in the case of equality. Q.E.D.

If a CEO chooses to raise debt, it is optimal to set the debt level as high as possible since tax benefits are increasing in the amount of debt while bankruptcy costs are fixed. If the CEO chooses full equity financing, he avoids bankruptcy costs, but gives up the tax benefits of debt. The optimum, then, is either full debt or full equity financing, depending on whether the expected tax benefits, $\tau p(w-d)$, outweigh expected bankruptcy costs, $(1-p) L$. Note that, in the simple two-state setup, the optimal capital structure never includes both risky debt and equity. However, interior leverage choices become optimal if we add an intermediate state in which the firm may or may not default depending on the level of debt chosen.

Now consider a CEO who overestimates the returns to investment, $\hat{E}[\cdot]>E[\cdot]$. Specifically, assume that the CEO overestimates returns by a fixed amount $\Delta$ in the good state, $\hat{R}_{G}=$ $R_{G}+\Delta$, but correctly perceives returns in the bad state, $\hat{R}_{B}=R_{B}$. This assumption allows us to isolate the mechanism which generates a preference for risky debt: over-valuation of the residual claim on cash flows in the good state.

Proposition 3 For the risky portion of investment, overconfident CEOs choose full debt financing (rather than equity financing) more often than rational CEOs.

Proof. Let $Q \equiv E\left[\left(\tilde{R}-\tau \mathbf{1}_{\{R>I\}}(\tilde{R}-I-[w-d])-w\right)^{+}\right]$. Denote as $\widehat{Q}$ an overconfident manager's perception of $Q$. Then, $\widehat{Q}=Q+p(1-\tau) \Delta$. Using (2), we can write the objective function of the overconfident CEO's maximization problem as $[Q-(I-d)] \frac{\widehat{Q}}{Q}$.

Consider first the case that the CEO uses at least some risky debt $\left(w>d>R_{B}\right)$. Then, using 
equations (5) and (6) and constraint (3), the maximand becomes

$$
\begin{aligned}
{[Q-(I-d)] \frac{\widehat{Q}}{Q}=} & {[Q-(I-d)]\left[1+\frac{p(1-\tau) \Delta}{Q}\right] } \\
= & {\left[(1-\tau) p R_{G}-(1-p \tau) I+(1-\tau)(1-p)\left(R_{B}-L\right)+\tau(1-p) d\right] . } \\
& {\left[1+\frac{p(1-\tau) \Delta}{(1-\tau) p R_{G}+p \tau I-(1-\tau)\left[d-(1-p)\left(R_{B}-L\right)\right]-p \tau d}\right] }
\end{aligned}
$$

Differentiating with respect to $d$ yields

$\frac{\partial}{\partial d}\left[\frac{Q-(I-d)}{Q} \widehat{Q}\right]=\tau(1-p)+\frac{\tau(1-p) p(1-\tau) \Delta}{Q}+\frac{p(1-\tau) \Delta[(1-\tau)+p \tau]}{Q^{2}}[Q-(I-d)]$.

The derivative is strictly positive if $Q>0$ and hence $s /\left(s+s^{\prime}\right) Q=Q-(I-d)>0$. We know that $Q \geq 0$ since it is defined as the expectation over values truncated at $0(Q \equiv$ $\left.E\left[\left(\tilde{R}-\tau 1_{\{R>I\}}(\tilde{R}-I-[w-d])-w\right)^{+}\right]\right)$. Since $Q=p\left[(1-\tau)\left(R_{G}-w\right)+\tau(I-d)\right]$ in the case of risky debt by (5), and $R_{G}-w \geq 0$ (since $w>R_{G}$ would yield lower payoffs to bondholders and stockholders than $w=R_{G}$ due to default costs in both states), and since $I-d \geq 0$ by (4), $Q=0$ if and only if $R_{G}-w=0$ and $I-d=0$. Thus, we have either $Q>0$, in which case the derivative is strictly positive and the manager sets $d$ as high as possible, $d^{*}=I$, or we have $Q=0$, which occurs also for $d=I$. In both cases, the maximand becomes:

$$
[Q-(I-d)] \frac{\widehat{Q}}{Q}=\widehat{Q}=(1-\tau)\left[p R_{G}+(1-p)\left(R_{B}-L\right)-I\right]+p(1-\tau) \Delta
$$

Now consider the case that $w=d=R_{B}$. Then, the firm finances $I$ using only riskless debt and equity. There is no default and using (7) and (8) the maximand becomes

$$
\begin{aligned}
{[Q-(I-d)] \frac{\widehat{Q}}{Q}=} & {[Q-(I-d)]\left[1+\frac{p(1-\tau) \Delta}{Q}\right] } \\
= & {\left[(1-\tau) p R_{G}-(1-p \tau) I+(1-p) R_{B}\right] } \\
& {\left[1+\frac{p(1-\tau) \Delta}{(1-\tau) p R_{G}+(1-p) R_{B}-R_{B}+p \tau I}\right] }
\end{aligned}
$$

Comparing the values of the objective function using the optimal amount of risky debt and all 
equity, we find that the manager chooses risky debt financing if and only if

$$
\begin{aligned}
& (1-\tau)\left[p R_{G}+(1-p)\left(R_{B}-L\right)-I\right]+p(1-\tau) \Delta \\
> & {\left[1+\frac{p(1-\tau) \Delta}{(1-\tau) p R_{G}+(1-p) R_{B}-R_{B}+p \tau I}\right]\left[(1-\tau) p R_{G}-(1-p \tau) I+(1-p) R_{B}\right] }
\end{aligned}
$$

Or,

$\tau(1-p)\left(I-R_{B}\right)+\left\{p(1-\tau) \Delta\left[1-\frac{(1-\tau) p R_{G}+(1-p) R_{B}-I+p \tau I}{(1-\tau) p R_{G}+(1-p) R_{B}-R_{B}+p \tau I}\right]\right\}>(1-\tau)(1-p) L$

Comparing this condition to condition (9) in Proposition 1, we see that the overconfident CEO will be more likely to use debt if and only if the term in \{\} is positive. Since $I>R_{B}$ by assumption, the term in [ ] is positive, yielding the result. Q.E.D.

An overconfident CEO is more likely to choose full debt financing than a rational CEO for two reasons. First, the CEO overestimates the tax benefits of debt since he overestimates future returns (i.e., overestimates cash flow $R_{G}$ by $\Delta$ ). Second, he perceives equity financing to be more costly since new shareholders obtain a partial claim on $\Delta$ without paying for it. In our simple set-up, the CEO agrees with the market about the fair interest rate on risky debt since there is no disagreement about the probability of default or the cash flow in default states.

In our simple setting, overconfidence does not affect the decision to implement a project, conditional on external financing. Since capital markets do not finance negative net present value projects, overconfident CEOs destroy value 'only' by using risky debt in some cases in which equity would be cheaper. If we re-introduce $A$ or $C$, overconfident CEOs may overinvest since they overvalue returns from investment and can finance negative net present value projects by diluting $A$ or spending out of $C$. Likewise, if we allow for CEOs to perceive $\widehat{A}>A$, overconfident CEOs might under-invest due to concern over diluting claims on existing assets. ${ }^{2}$

Since we used $\hat{R}_{B}>R_{B}$ to argue that overconfident CEOs prefer internal finance to risky debt, we briefly consider the choice between risky debt and equity for a CEO who overestimates not only $R_{G}$ but also $R_{B}$, e.g. $\hat{R}_{B}=R_{B}+\Delta$. If $\hat{R}_{B} \geq w \geq R_{B}$, overconfident CEOs mistakenly believe that they will not default in the bad state. If the probability of default is large and

\footnotetext{
${ }^{2}$ Propositions 1 and 2 of Malmendier and Tate (2004) derive these results formally in a parallel setup for external investment projects (mergers).
} 
$\Delta$ is small, the CEO may misperceive debt financing to be more costly than equity financing, reversing the preference for risky debt over equity. Hence, Proposition 3 may fail in some cases. Intuitively, creditors seize all of $\Delta$ in the event of default on risky debt, but equity holders receive only a fraction of $\Delta$ in the bad state.

Overall, our analysis demonstrates that overconfidence can generate a preference for risky debt over equity, conditional on accessing external capital markets. This preference arises because overconfident CEOs prefer being the residual claimant on the full cash flow in non-default states to giving up a fraction of cash flows in all states. In addition, overconfident CEOs may exhibit debt conservatism. They raise little external financing of any kind, in particular less risky debt than rational CEOs. In other words, the absolute amount of debt used by overconfident CEOs can be smaller even if leverage is higher (due to less frequent equity issuance), as illustrated in Figure 1. 


\section{References}

[1] Malmendier, Ulrike, and Tate, Geoffrey A., 2004, Who Makes Acquisitions? CEO Overconfidence and the Market's Reaction, NBER Working Paper 10813. 